\title{
Hedging Effectiveness of Constant and Time Varying Hedge Ratio in Indian Stock and Commodity Futures Markets
}

\author{
Brajesh Kumar \\ Priyanka Singh \\ Ajay Pandey
}

W.P. No.2008-06-01

June 2008

The main objective of the working paper series of the IIMA is to help faculty members, research staff and doctoral students to speedily share their research findings with professional colleagues and test their research findings at the pre-publication stage. IIMA is committed to maintain academic freedom. The opinion(s), view(s) and conclusion(s) expressed in the working paper are those of the authors and not that of IIMA.

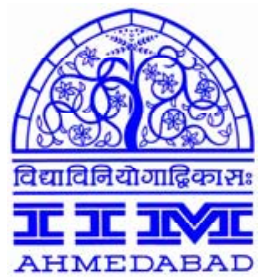

INDIAN INSTITUTE OF MANAGEMENT

AHMEDABAD-380 015

INDIA 


\title{
Hedging Effectiveness of Constant and Time Varying Hedge Ratio in Indian Stock and Commodity Futures Markets
}

\author{
Brajesh Kumar ${ }^{1}$ \\ Priyanka Singh ${ }^{2}$ \\ Ajay Pandey
}

\begin{abstract}
This paper examines hedging effectiveness of futures contract on a financial asset and commodities in Indian markets. In an emerging market context like India, the growth of capital and commodity futures market would depend on effectiveness of derivatives in managing risk. For managing risk, understanding optimal hedge ratio is critical for devising effective hedging strategy. We estimate dynamic and constant hedge ratio for S\&P CNX Nifty index futures, Gold futures and Soybean futures. Various models (OLS, $V A R$, and VECM) are used to estimate constant hedge ratio. To estimate dynamic hedge ratios, we use VAR-MGARCH. We compare in-sample and out-of-sample performance of these models in reducing portfolio risk. It is found that in most of the cases, VARMGARCH model estimates of time varying hedge ratio provide highest variance reduction as compared to hedges based on constant hedge ratio. Our results are consistent with findings of Myers (1991), Baillie and Myers (1991), Park and Switzer (1995a,b), Lypny and Powella (1998), Kavussanos and Nomikos (2000), Yang (2001), and Floros and Vougas (2006).
\end{abstract}

Keywords: Hedging Effectiveness, Hedge ratio, Bivariate GARCH, S\&P CNX Nifty index and futures, Commodity futures

\footnotetext{
${ }^{1}$ Doctoral Student, Indian Institute of Management, Ahmedabad (Email: brajeshk@iimahd.ernet.in)

${ }^{2}$ Doctoral Student, Indian Institute of Management, Ahmedabad (Email: priyankas@iimahd.ernet.in)

${ }^{3}$ Professor, Finance and Accounting Area, Indian Institute of Management, Ahmedabad, India

(Email: apandey@,iimahd.ernet.in)
} 


\section{INTRODUCTION}

Rising price volatility has led to a number of specialized financial instruments that allow participants to hedge against unexpected price movement. Like any other derivative, futures contracts can be used as an insurance against unfavorable price fluctuations. In Indian context, S\&P CNX Nifty index futures and commodity futures are comparatively new and were introduced in the year 2000 and 2003 respectively. In last 4-5 years, the Indian stocks as well as commodity markets have grown considerably ${ }^{4}$. Bose (2007) found that Indian stock markets are more volatile as compared to developed markets. Indian commodity futures markets are going through many ups and downs and many a times allegations of speculative activity have been made in the popular press. Despite controversies, there is a need for systematic investigation of stock and commodity derivatives markets to asses their effectiveness in transferring the risk. This research investigates the hedging effectiveness provided by the futures market. Hedging effectiveness of futures markets is one of the important determinants of success of futures contracts (Silber, 1985; Pennings \& Meulenberg, 1997).

Price risk management, using hedging tools like futures and options and their effectiveness, is an active area of research. Hedging decisions based on futures contracts have to deal with finding optimal hedge ratio and hedging effectiveness. Role of hedging using multiple risky assets and using futures market for minimizing the risk of spot market fluctuation has been extensively researched. Several distinct approaches have been developed to estimate the optimal hedge ratio. Techniques like OLS, VAR, and VECM estimate constant hedge ratio and bivariate GARCH models estimates dynamic hedge ratios which factor in conditional distribution of spot and futures returns. However, there has been extensive debate on which model generates the best hedging performance (Baillie \& Myers, 1991; Ghosh, 1993; Park \& Switzer, 1995; Kavussanos \& Nomikos, 2000; Lien et al., 2002; Moosa; 2003, Floros \& Vougas, 2006). Superior performance of bivariate GARCH models was supported by Baillie and Myers (1991), Park and Switzer, (1995), Kavussanos and Nomikos, (2000), Floros and Vougas (2006) etc. Ghosh (1993), however, found better performance of VECM among constant hedge models and Lien et al. (2002) and Moosa (2003) found that the basic OLS approach clearly dominates other alternatives.

\footnotetext{
${ }^{4}$ http://indiabudget.nic.in/es2007-08/chapt2008/chap53.pdf
} 
Traditionally, hedging is envisaged using a hedge ratio of '-1', i.e., taking a position in futures contract which is equal in magnitude and opposite in sign to the position in spot market. If the movement of changes in spot prices and futures prices is exactly the same, then such a strategy eliminates the price risk. Such a perfect correlation between spot and futures prices is rarely observed in markets and hence a need was felt for a better strategy. Johnson (1960) proposed 'minimum variance hedge ratio (MVHR)', which factored in less than perfect relationship between spot and futures prices.. Risk was defined as the variance of returns on a two-asset hedged position.

The Minimum-Variance Hedge Ratio (Benninga, et al., 1983, 1984) has been suggested as slope coefficient of the OLS regression in which changes in spot prices is regressed on changes in futures price. The optimal hedge ratio for any unbiased futures market can be given by ratio of covariance of (cash Prices, futures Prices) and variance of (futures Prices). In other words, MVHR is the regression coefficient of the regression model (changes in spot prices over changes in futures prices) which gives maximum possible variance reduction or hedging effectiveness.

Many researchers have defined hedging effectiveness as the extent of reduction in variances as a risk minimization problem (Johnson, 1960; Ederington, 1979). However, Rolfo (1980) and Anderson and Danthine (1981) calculated optimal hedge ratio by maximizing traders' expected utility, which is determined by both expected return and variance of portfolio. Because of the relationship (trade-off) between risk and return, they argued that optimal ratio must be estimated in mean-variance framework rather than for minimizing only risk.

Using OLS regression for estimating the hedge ratio and assessing hedging effectiveness based on its R-square, has been criticized mainly on two grounds (Baillie \& Myers, 1991; Park \& Switzer, 1995). First, the hedge ration estimated using OLS regression is based on assumption of unconditional distribution of spot and futures prices; whereas, the use of conditional distributions is more appropriate because hedging decision made by any hedger is based on all the information available at that time. Second, OLS model is based on assumption that the relationship between spot and future prices is time invariant but empirically it has been found that the joint distribution of spot and futures prices are time variant (Mandelbrot, 1963; Fama, 1965). 
Recent advancements in the time series modeling techniques have tried to remove the deficiencies of the OLS estimation. Multivariate GARCH (Bollerslev et al, 1988) has been used to calculate time varying hedge ratio. Many recent works on the hedging effectiveness estimate time varying hedge ratios (Baillie \& Myers, 1991; Park \& Switzer, 1995; Holmes, 1995; Lypny \& Powella, 1998; Kavussanos \& Nomikos, 2000; Choudhry, 2004; Floros \& Vougas, 2006; Bhaduri \& Durai, 2008). Park and Switzer applied MGARCH approach to calculate hedge effectiveness of three types of stock index futures: S\&P 500, MMI futures and Toronto 35 index futures and found that Bivariate GARCH estimation improves the hedging performance. Lypny and Powella (1998) used VEC-MGARCH $(1,1)$ model to examine the hedging effectiveness of German stock Index DAX futures and found that dynamic model was superior than constant hedge model. However, some recent studies such as those of Lien et al. (2002) and Moosa (2003) have found that the basic OLS approach clearly dominates. Thus, empirical findings across markets seem to suggest that the best model for hedging may be country and market specific.

There are very few empirical investigations of the stock futures markets and hedge ratios in emerging market context (Choudhry, 2004; Floros \& Vougas, 2006; Bhaduri \& Durai, 2008) and especially in context of Indian commodity futures. Choudhary (2004) investigated the hedging effectiveness of Australian, Hong Kong, and Japanese stock futures markets. Both constant hedge models and time varying models were used to estimate and compare the hedge ratio and hedging effectiveness. He found that timevarying GARCH hedge ratio outperformed the constant hedge ratios in most of the cases, inside-the-sample as well as outside-the-sample. Floros and Vougas (2006) studied the hedging effectiveness in Greek Stock index futures market for the period of 1999-2001 and found that time varying hedge ratio estimated by GARCH model provides highest variance reduction as compared to the other methods. Bhaduri and Durai (2008) found similar results while analyzing the effectiveness of hedge ratio through mean return and variance reduction between hedge and unhedged position for various horizon periods of NSE Stock Index Futures. However, the simple OLS-based strategy also performed well at shorter time horizons. Roy and Kumar (2007) studied hedging effectiveness of wheat futures in India using least square method and found that hedging effectiveness provided by futures markets was low (15\%). 
Since the hedging effectiveness has been found to be contingent on model used to estimate hedge ratio and whether it is kept constant or allowed to vary over the hedging horizon, it is interesting to investigate the same in Indian context. While there has been some work in this direction for the Stock Index Futures, Indian Commodity Futures have not been extensively researched empirically on the choice of model for estimating hedge ratio and resultant hedge effectiveness. Presumably, this research would help in understanding effectiveness of commodity futures contracts once the relationship between spot and futures prices is modeled and factored in estimating hedge ratio. It may also help concerned exchanges and the government to devise better risk management tools or supports towards commodity-specific public policy objectives. At the time of writing this paper, reports suggest that the Indian government is planning on aggregation model to encourage participation of farmers on the commodity exchanges. Finally, this study may help hedgers in devising better hedging strategies.

This study investigates optimal hedge ratio and hedge effectiveness of select futures contracts from Indian markets. Three different futures contracts have been empirically investigated in this study. One of these is a Stock index futures on S\&P CNX Nifty, which is a value-weighted index consisting of 50 large capitalization stocks maintained by National Stock Exchange. The other two futures contracts are- Gold futures and Soybean futures. All futures contracts traded in the market at any point in time have been considered. Daily closing price data on S\&P CNX Nifty index and its futures contracts ${ }^{5}$ (all three) available at any given time, and similarly three Gold futures ${ }^{6}$ and three Soybean futures ${ }^{7}$ contracts trading contemporaneously are included. Since hedge effectiveness of NIFTY futures was investigated by Bhaduri and Durai (2008) for the period 4 September 2000 to 4 August 2005, we have used data for the period of $1^{\text {st }}$ Jan 2004 to $8^{\text {th }}$ May 2008 of NIFTY futures to supplement their work.

This paper is organized as follows: several model specifications used for estimating the hedge effectiveness and hedge ratio are presented in Section 2. In Section 3, description

\footnotetext{
${ }^{5}$ S\&P CNX Nifty futures contracts have a maximum of 3-month trading cycle - the near month (one), the next month (two) and the far month (three). A new contract is introduced on the trading day following the expiry of the near month contract (http://www.nseindia.com)

${ }^{6}$ Gold futures contracts are started from $22^{\text {nd }}$ July 2005 on NCDEX and there are only three contemporary futures contacts of different maturity (http://www.ncdex.com).

${ }^{7}$ Soybean futures are stared prior to $4^{\text {th }}$ October 2004on NCDEX; however, because of less trading volume, futures prices before $4^{\text {th }}$ October 2004, were behaving erratically, we considered the data from abovementioned date. We are able to construct three contemporary series of futures prices for the total period.
} 
of the data used for the study and its characteristics is given. Results are presented in Section 4 and the final section concludes the findings of the study.

\section{HEDGE RATIO AND HEDGING EFFECTIVENESS}

In this study, four models, conventional OLS, VAR, VEC and VAR-MGARCH are employed to estimate optimal hedge ratio. The OLS, VAR and VECM models estimate constant hedge ratio whereas time varying optimal hedge ratios are calculated using bivariate GARCH model (Bollerslev et al., 1988). In this section, first we discuss the hedge ratio and hedging effectiveness and then all four models are presented.

In portfolio theory, hedging with futures can be considered as a portfolio selection problem in which futures can be used as one of the assets in the portfolio to minimize the overall risk or to maximize utility function. Hedging with futures contracts involves purchase/sale of futures in combination with another commitment, usually with the expectation of favorable change in relative prices of spot and futures market (Castelino, 1992). The basic idea of hedging through futures market is to compensate loss/ profit in futures market by profit/loss in spot markets.

The optimal hedge ratio is defined as the ratio of the size of position taken in the futures market to the size of the cash position which minimizes the total risk of portfolio. The return on an unhedged and a hedged portfolio can be written as:

$R_{U}=S_{t+1}-S_{t}$
$R_{H}=\left(S_{t+1}-S_{t}\right)-H\left(F_{t+1}-F_{t}\right)$

Variances of an unhedged and a hedged portfolio are:

$$
\begin{aligned}
& \operatorname{Var}(U)=\sigma_{S}^{2} \\
& \operatorname{Var}(H)=\sigma_{S}^{2}+H^{2} \sigma_{F}^{2}-2 H \sigma_{S, F}
\end{aligned}
$$

where, $S_{t}$ and $F_{t}$ are natural logarithm of spot and futures prices, $H$ is the hedge ratio, $R_{H}$ and $\mathrm{R}_{\mathrm{U}}$ are return from unhedged and hedged portfolio, $\sigma_{\mathrm{S}}$ and $\sigma_{\mathrm{F}}$ are standard deviation of the spot and futures return and $\sigma_{\mathrm{S}, \mathrm{F}}$ is the covariance.

Hedging effectiveness is defined as the ratio of the variance of the unhedged position minus variance of hedge position over the variance of unhedged position.

Hedging Effectiveness $(E)=\frac{(\operatorname{Var}(U)-\operatorname{Var}(H))}{\operatorname{Var}(U)}$ 


\subsection{MODELS FOR CALCULATING HEDGING EFFECTIVENESS AND HEDGE RATIO}

Several models have been used to estimate hedge ratio and hedging effectiveness such as conventional OLS model, Vector Autoregressive regression (VAR) model, Vector Error Correction model (VECM), Vector Autoregressive Model with Bivariate Generalized Autoregressive Conditional Heteroscedasticity model (VAR-MGARCH). Hedge performance estimated by OLS, VAR, and VECM is based on assumption that the joint distribution of spot and futures prices is time invariant and does not take into account the conditional covariance structure of spot and futures price, whereas VAR-MGARCH model estimates time varying hedge ratio and time varying conditional covariance structure of spot and futures price.

\subsubsection{MODEL 1: OLS METHOD}

In this method changes in spot price is regressed on the changes in futures price. The Minimum-Variance Hedge Ratio has been suggested as slope coefficient of the OLS regression. It is the ratio of covariance of (spot prices, futures prices) and variance of (futures prices). The R-square of this model indicates the hedging effectiveness. The OLS equation is given as:

$$
R_{S t}=\alpha+H R_{F t}+\varepsilon_{t}
$$

Where, $R_{S t}$ and $R_{F t}$ are spot and futures return, $H$ is the optimal hedge ratio and $\varepsilon_{t}$ is the error term in the OLS equation. Many empirical studies use the OLS method to estimate optimal hedge ratio, however this method does not take account of conditioning information (Myers \& Thompson, 1989) and ignores the time varying nature of hedge ratios (Cecchetti, Cumby, \& Figlewski, 1988). It also does not consider the futures returns as endogenous variable and ignores the covariance between error of spot and futures returns. The advantage of this model is the ease of implementation.

\subsubsection{MODEL 2: THE BIVARIATE VAR MODEL}

The bivariate VAR Model is preferred over the simple OLS estimation because it eliminates problems of autocorrelation between errors and treat futures prices as endogenous variable. The VAR model is represented as 


$$
\begin{aligned}
& R_{S t}=\alpha_{S}+\sum_{i=1}^{k} \beta_{S i} R_{S t-i}+\sum_{j=1}^{l} \gamma_{F j} R_{F t-j}+\varepsilon_{S t} \\
& R_{F t}=\alpha_{F}+\sum_{i=1}^{k} \beta_{F i} R_{F t-i}+\sum_{j=1}^{l} \gamma_{S j} R_{S t-j}+\varepsilon_{F t}
\end{aligned}
$$

The error terms in the equations, $\varepsilon_{\mathrm{St}}$, and $\varepsilon_{\mathrm{Ft}}$ are independently identically distributed (IID) random vector. The minimum variance hedge ratio are calculated as

$$
H=\frac{\sigma_{s f}}{\sigma_{f}}
$$

where,

$\operatorname{Var}\left(\varepsilon_{S t}\right)=\sigma_{s}$

$\operatorname{Var}\left(\varepsilon_{F t}\right)=\sigma_{f}$

$\operatorname{Cov}\left(\varepsilon_{S t}, \varepsilon_{S t}\right)=\sigma_{s f}$

The VAR model does not consider the conditional distribution of spot and futures prices and calculates constant hedge ratio. It does not consider the possibility of long term integration between spot and futures returns.

\subsubsection{MODEL 3: THE ERROR CORRECTION MODEL}

VAR model does not consider the possibility that the endogenous variables could be cointegrated in the long term. If two prices are co-integrated in long run then Vector Error Correction model is more appropriate which accounts for long-run co-integration between spot and futures prices (Lien \& Luo, 1994; Lien, 1996). If the futures and spot series are co-integrated of the order one, then the Vector error correction model of the series is given as:

$$
\begin{aligned}
& R_{S t}=\alpha_{S}+\beta_{S} S_{t-1}+\gamma_{F} F_{t-1}+\sum_{i=2}^{k} \beta_{S i} R_{S t-i}+\sum_{j=2}^{l} \gamma_{F j} R_{F t-j}+\varepsilon_{S t} \\
& R_{F t}=\alpha_{F}+\beta_{F} F_{t-1}+\gamma_{S} S_{t-1}+\sum_{i=21}^{k} \beta_{F i} R_{F t-i}+\sum_{j=2}^{l} \gamma_{S j} R_{S t-j}+\varepsilon_{F t}
\end{aligned}
$$

where, $S_{t}$ and $F_{t}$ are natural logarithm of spot and futures prices. The assumptions about the error terms are same as for VAR model. The minimum variance hedge ratio and hedging effectiveness are estimated by following similar approach as in case of VAR model. 


\subsubsection{MODEL 4: THE VAR-MGARCH MODEL}

Generally, time series data of return possesses time varying heteroscedastic volatility structure or ARCH-effect (Bollerslev et al, 1992). Due to ARCH effect in the returns of spot and futures prices and their time varying joint distribution, the estimation of hedge ratio and hedging effectiveness may turn out to be inappropriate. Cecchetti, Cumby, and Figlewski (1988) used ARCH model to represent time variation in the conditional covariance matrix of Treasury bond returns and bond futures to estimate time-varying optimal hedge ratios and found substantial variation in optimal hedge ratio. The VARMGARCH model considers the ARCH effect of the time series and calculate time varying hedge ratio. A bivariate $\operatorname{GARCH}(1,1)$ model is given by:

$$
\begin{aligned}
& R_{S t}=\alpha_{S}+\sum_{i=1}^{k} \beta_{S i} R_{S t-i}+\sum_{j=1}^{l} \gamma_{F j} R_{F t-j}+\varepsilon_{S t} \\
& R_{F t}=\alpha_{F}+\sum_{i=1}^{k} \beta_{F i} R_{F t-i}+\sum_{j=1}^{l} \gamma_{S j} R_{S t-j}+\varepsilon_{F t} \\
& {\left[\begin{array}{l}
h_{s s} \\
h_{s f} \\
h_{f f}
\end{array}\right]=\left[\begin{array}{l}
C_{s s} \\
C_{s f} \\
C_{f f}
\end{array}\right]_{t}\left[\begin{array}{lll}
\alpha_{11} & \alpha_{12} & \alpha_{13} \\
\alpha_{21} & \alpha_{22} & \alpha_{23} \\
\alpha_{31} & \alpha_{32} & \alpha_{33}
\end{array}\right]\left[\begin{array}{c}
\varepsilon_{s}^{2} \\
\varepsilon_{s} \varepsilon_{f} \\
\varepsilon_{f}^{2}
\end{array}\right]_{t-1}+\left[\begin{array}{lll}
\beta_{11} & \beta_{12} & \beta_{13} \\
\alpha_{21} & \beta_{22} & \beta_{23} \\
\beta_{31} & \beta_{32} & \beta_{33}
\end{array}\right]\left[\begin{array}{l}
h_{s s} \\
h_{s f} \\
h_{f f}
\end{array}\right]_{t-1}}
\end{aligned}
$$

where, $h_{\mathrm{ss}}$ and $\mathrm{h}_{\mathrm{ff}}$ are the conditional variance of the errors $\varepsilon_{\mathrm{st}}$ and $\varepsilon_{\mathrm{ft}}$ and $\mathrm{h}_{\mathrm{sf}}$ is the covariance.

Bollerslev et al. (1988) proposed a restricted version of the above model in which the only diagonal elements of $\boldsymbol{\alpha}$ and $\boldsymbol{\beta}$ matrix are considered and the correlations between conditional variances are assumed to be constant. The diagonal representation of the conditional variances elements $h_{s s}$ and $h_{f f}$ and the covariance element $h_{s f}$ is presented as (Bollerslev et al., 1988):

$$
\begin{aligned}
& h_{s s, t}=C_{s s}+\alpha_{s s} \varepsilon_{s, t-1}^{2}+\beta_{s s} h_{s s, t-1} \\
& h_{s f, t}=C_{s f}+\alpha_{s f} \varepsilon_{s, t-1} \varepsilon_{f, t-1}+\beta_{s f} h_{s f, t-1} \\
& h_{f f, t}=C_{f f}+\alpha_{f f} \varepsilon_{f, t-1}^{2}+\beta_{f f} h_{f f, t-1}
\end{aligned}
$$


Time varying hedge ratio is calculated as follows:

$$
H_{t}=\frac{h_{\text {sft }}}{h_{f f t}}
$$

\section{CHARACTERISTICS OF FUTURES PRICES}

Daily closing price data on S\&P CNX Nifty index and its futures contracts, published by NSE India, for the period from $1^{\text {st }}$ January 2004 to $8^{\text {th }}$ May 2008 has been analyzed in this study. All three futures contracts trading at a given point of time are analyzed and compared. Data for the period of $21^{\text {st }}$ February 2008 to $8^{\text {th }}$ May 2008 has been used for out-of-the-sample analysis. Similarly, two Gold futures for the period from $22^{\text {nd }}$ July 2005 to $8^{\text {th }}$ May 2008 and two Soybean futures from $4^{\text {th }}$ October 2004 to $8^{\text {th }}$ May 2008 are also considered. For Gold and Soybean, data for the period of $21^{\text {st }}$ February 2008 to $8^{\text {th }}$ May 2008 and $1^{\text {st }}$ January 2008 to $8^{\text {th }}$ may 2008 has been are used for out-of-the-sample analysis respectively. These commodities are traded on National Commodity Exchange, India. Spot prices obtained from the commodity exchanges are not reliable as there is no spot trading and they are collected from some regional markets. These prices might not be a true representation of spot prices because of market imperfection, difference in quality and policy restriction on the movement of commodities. Hence, following Fama and French (1987), Bailey and Chan (1993), Bessembinder et al. (1995), Mazaheri (1999) and Frank and Garcia (2008), the nearby futures prices Gold and Soybean are used as a proxy for the spot price and the subsequent futures price as the futures price. Time series of spot and futures prices of these assets are given in Figure 1. 


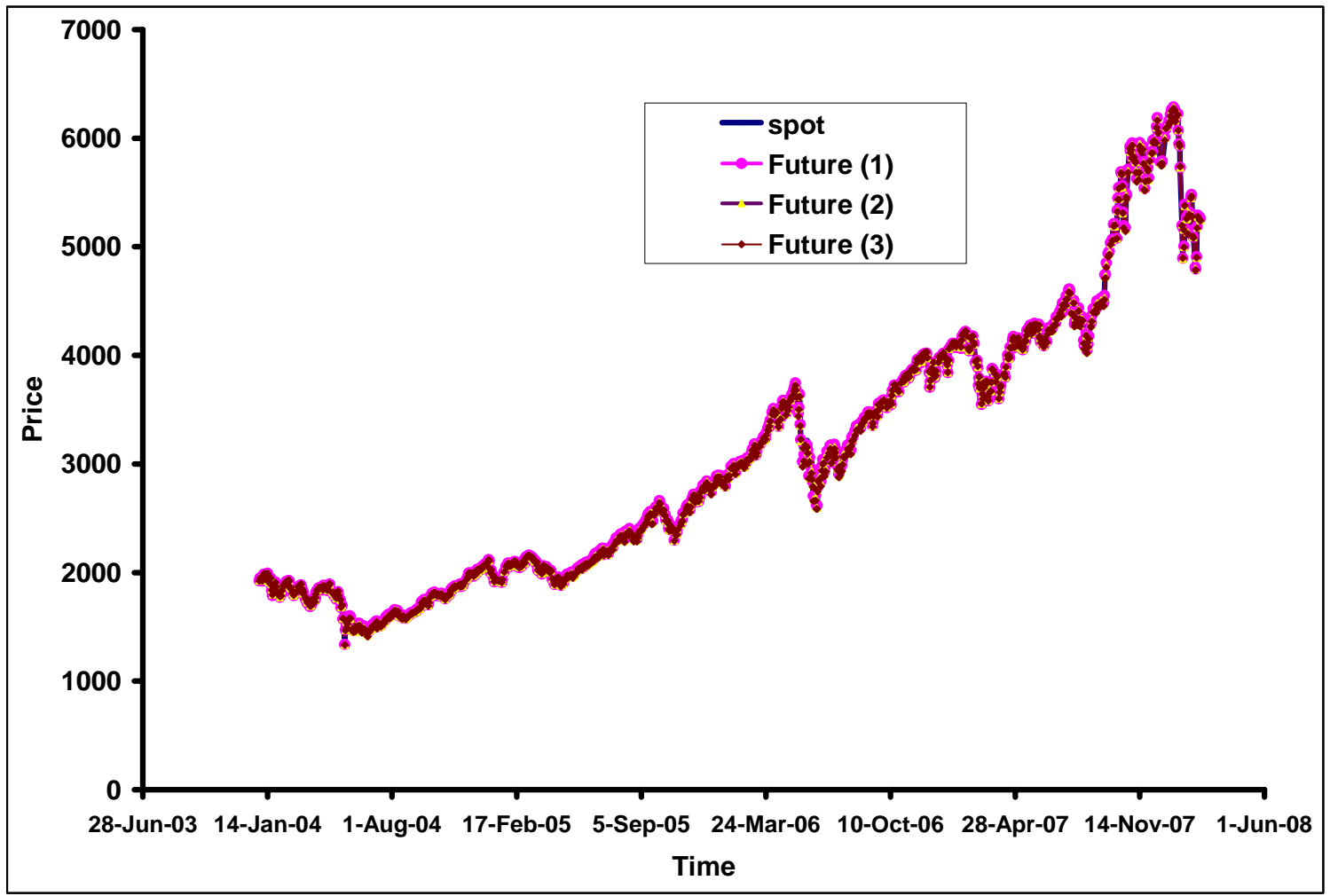

a) Nifty

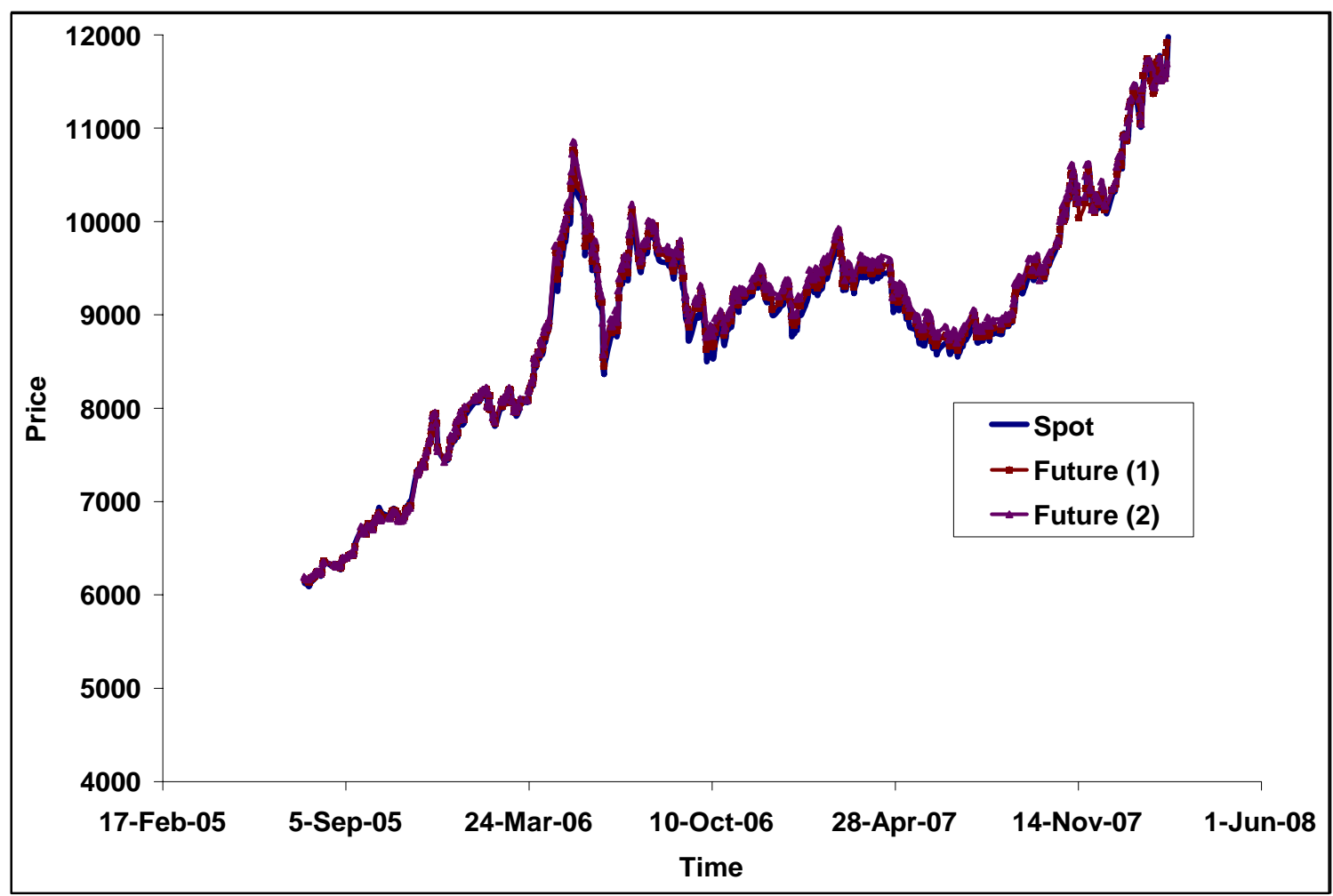

b) Gold 


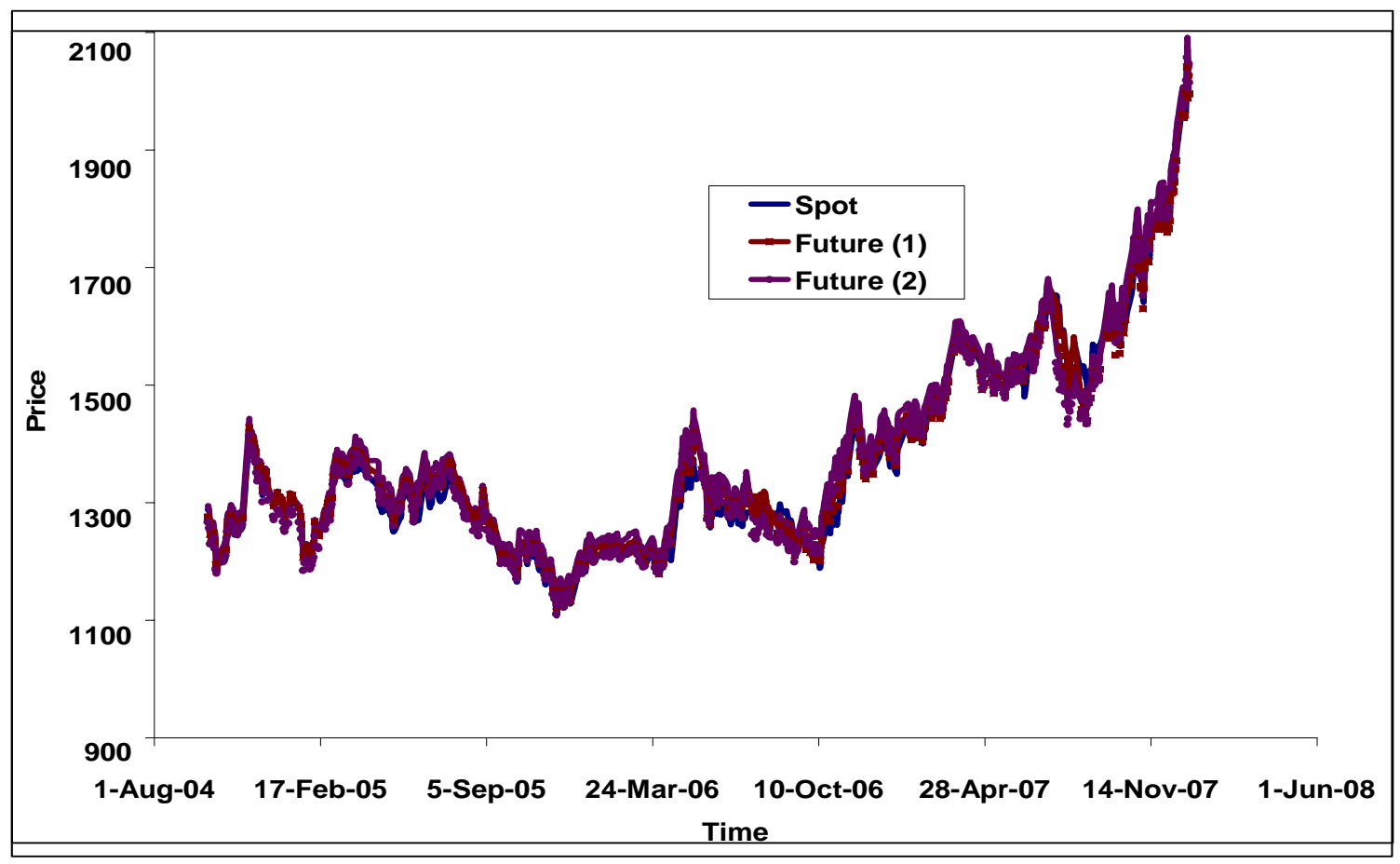

c) Soybean

Figure 1: Spot and futures prices of a) Nifty b) Gold and c) Soybean

\section{1: TEST OF UNIT ROOT AND COINTEGRATION}

Stationarity of the prices and their first difference are tested using ADF and KPSS test statistics. KPSS is often suggested as a confirmatory test of stationarity. The null hypothesis for ADF test is that the series contains unit root whereas stationarity of the series is used as the null hypothesis for KPSS test. The summary statistics are shown in Table 1.

Table 1: Unit root tests on prices and returns

\begin{tabular}{|c|l|r|r|l|r|r|}
\hline \multirow{2}{*}{ Asset } & \multicolumn{1}{|c|}{$\begin{array}{c}\text { Price } \\
\text { series }\end{array}$} & ADF (t stat) & $\begin{array}{c}\text { KPSS (LM } \\
\text { stat) }\end{array}$ & $\begin{array}{c}\text { Return } \\
\text { series }\end{array}$ & ADF (t stat) & $\begin{array}{c}\text { KPSS (LM } \\
\text { stat) }\end{array}$ \\
\hline \multirow{3}{*}{ Nifty } & Spot & -3.1287 & $0.518785^{* *}$ & Spot & $-30.512^{* *}$ & 0.053376 \\
\cline { 2 - 7 } & Future1 & -3.0217 & $0.512487 * *$ & Future1 & $-32.2084 * *$ & 0.061826 \\
\cline { 2 - 7 } & Future2 & -3.0141 & $0.510871^{* *}$ & Future2 & $-32.31197 * *$ & 0.054473 \\
\cline { 2 - 7 } & Future3 & -3.0036 & $0.512137 * *$ & Future3 & $-32.27063 * *$ & 0.051550 \\
\hline \multirow{3}{*}{ Gold } & Spot & -1.4494 & $0.349708^{* *}$ & Spot & $-24.59546 * *$ & 0.156087 \\
\cline { 2 - 7 } & Future1 & -1.4692 & $0.364389^{* *}$ & Future1 & $-23.59079 * *$ & 0.128691 \\
\cline { 2 - 7 } & Future2 & -1.7648 & $0.374682^{* *}$ & Future2 & $-22.9685^{* *}$ & 0.123841 \\
\hline \multirow{3}{*}{ Soybean } & Spot & -0.2678 & $0.745553^{* *}$ & Spot & $-27.48925^{* *}$ & 0.047505 \\
\cline { 2 - 7 } & Future1 & -0.1900 & $0.692446^{* *}$ & Future1 & $-28.09060^{* *}$ & 0.031771 \\
\cline { 2 - 7 } & Future2 & -1.2823 & $0.240624 * *$ & Future2 & $-27.99354 * *$ & 0.035745 \\
\hline
\end{tabular}

$*(* *)$ denotes rejection of the hypothesis at the $5 \%(1 \%)$ level

\footnotetext{
${ }^{8}$ The near month futures are named as Future 1, next to near month futures as Future 2 and Future 3 subsequently. So for Nifty futures there are three futures series (Future 1, Future 2 and Future 3) and for Gold and Soybean, there are two futures series only.
} 
Both ADF and KPSS test statistics confirm that all prices have unit root (non-stationary) and return series are stationary. They have one degree of integration (I(1)- process). The co-integration between spot and futures prices is tested by Johansen's (1991) maximum likelihood method. The results of co-integration are presented in Table 2. It can be observed that spot and futures prices have one co-integrating vector and they are cointegrated in the long run.

Table 2: Johansen co-integration tests of spot and futures prices

\begin{tabular}{|c|c|c|c|c|c|c|c|}
\hline & & \multicolumn{2}{|c|}{ Spot-Future 1} & \multicolumn{2}{|c|}{ Spot-Future 2} & \multicolumn{2}{|c|}{ Spot-Future 3} \\
\hline & Hypothesized & & Trace & Eigenvalu & Trace & & Trace \\
\hline & No. of CE(s) & Eigenvalue & Statistic & e & Statistic & Eigenvalue & Statistic \\
\hline \multirow[b]{2}{*}{ Nifty } & None & $0.04048 * *$ & $43.028 * *$ & $0.01973 * *$ & $22.3309 * *$ & $0.014 * *$ & $16.737 * *$ \\
\hline & At most 1 & 0.00236 & 2.325366 & 0.002744 & 2.706341 & 0.0029 & 2.8595 \\
\hline \multirow[b]{2}{*}{ Gold } & None & $0.02739 * *$ & $20.726 * *$ & $0.02351 * *$ & 18.62156 & -- & -- \\
\hline & At most 1 & 0.0046 & 2.950516 & 0.005287 & 3.392959 & -- & -- \\
\hline \multirow[b]{2}{*}{ Soybean } & None & $0.02551 * *$ & $23.823 * *$ & $0.01589 * *$ & $13.6849 * *$ & -- & - \\
\hline & At most 1 & 0.00408 & 3.255157 & 0.00117 & 0.931647 & -- & -- \\
\hline
\end{tabular}

$*(* *)$ denotes rejection of the hypothesis at the $5 \%(1 \%)$ level

\section{HEDGE RATIO AND EFFECTIVENSS: EMPIRICAL PERFORMANCE OF MODELS}

Hedge ratio and hedging effectiveness of Index futures (Nifty) and commodity futures (Soybean and Gold) is estimated through four models (OLS, VAR, VECM and bivariate GARCH) described earlier. We also estimated the time varying hedge ratio for Nifty and Gold futures by VAR-MGARCH approach ${ }^{9}$. In-sample and out-of-sample estimates of hedge ratio and hedging effectiveness calculated from these models are compared.

\subsection{IN-SAMPLE RESULTS}

\subsubsection{OLS ESTIMATES}

OLS regression (equation [4]) has been used to calculate the hedge ratio and hedging effectiveness. The slope of the regression equation gives the hedge ratio and $\mathrm{R}^{2}$, the hedging effectiveness.

\footnotetext{
${ }^{9}$ For Soybeans futures, we did not get the optimized solution. As addressed by Bera and Higgins (1993), one disadvantage of Diagonal GARCH models is that the covariance matrix is not always positive definite and therefore the numerical optimization of likelihood function may fail.
} 
Table 3: OLS regression model estimates

\begin{tabular}{|c|c|c|c|c|c|c|c|}
\hline & \multicolumn{3}{|c|}{ Nifty } & \multicolumn{2}{c|}{ Gold } & \multicolumn{3}{c|}{ Soybean } \\
\hline & Future 1 & Future 2 & Future 3 & Future 1 & Future 2 & Future 1 & Future 2 \\
\hline $\boldsymbol{\alpha}$ & -0.00708 & -0.00172 & 0.00209 & 0.01025 & 0.01986 & $-0.02749 *$ & $-0.03430^{*}$ \\
\hline $\boldsymbol{\beta}$ & $0.91181 *$ & $0.90519 *$ & $0.90836^{*}$ & $0.92387 *$ & $0.73613^{*}$ & $0.93092^{*}$ & $0.90329 *$ \\
\hline $\mathbf{R}^{\mathbf{2}}$ & 0.9696 & 0.9641 & 0.9483 & 0.8076 & 0.4749 & 0.9264 & 0.8856 \\
\hline
\end{tabular}

$* *(*)$ denotes significance of estimates at $5 \%(10 \%)$ level

For all futures contracts, the hedge ratio is higher than 0.90 except for Gold far month maturity contract (Future 2). Hedge ratio estimated from OLS method provides approximately 90\% variance reduction except for Gold far month maturity contract (Future 2), which indicates that the hedge provided by these contracts in Indian markets is effective. Hedging effectiveness was highest for Nifty futures. Near month Gold futures provides $81 \%$ of hedging effectiveness as compared to $47 \%$ for distant futures. Hedging effectiveness decreases as we move from near-month futures to distant futures (except Nifty futures where this decrease is not very high).

\subsubsection{VAR ESTIMATES}

To calculate the hedge ratio and hedging effectiveness, system of equations (equation [5]) is solved and errors are estimated. We used errors from the equation [5] to calculate hedge ratio and hedging effectiveness (equation [6]) of futures contracts. The estimates of the parameters of the spot and futures equations are given in Table 3 and the optimal hedge ratio and hedge effectiveness is presented in Table 4.

\section{Table 3: Estimates of VAR model}

\section{a) Spot prices}

\begin{tabular}{|c|c|c|c|c|c|c|c|}
\hline & \multicolumn{3}{|c|}{ Nifty } & \multicolumn{2}{|c|}{ Gold } & \multicolumn{2}{|c|}{ Soybean } \\
\hline & Future 1 & Future 2 & Future 3 & Future 1 & Future 2 & Future 1 & Future 2 \\
\hline$\alpha$ & 0.09214 & 0.08637 & 0.08509 & 0.06614 & 0.06546 & 0.00085 & -0.00353 \\
\hline$\beta_{\mathrm{S} 1}$ & 0.14468 & 0.2071 & 0.12434 & 0.09816 & $0.11122 * *$ & -0.19642 & -0.13519 \\
\hline$\beta_{\mathrm{S} 2}$ & -0.12895 & -0.16246 & $-0.30353^{*}$ & $0.36298 * *$ & 0.12681 & 0.03143 & -0.07937 \\
\hline$\beta_{\mathrm{S} 3}$ & 0.10678 & -0.03455 & -0.03626 & 0.09341 & $-0.00594 *$ & 0.04543 & 0.00736 \\
\hline$\beta_{\mathrm{S} 4}$ & $0.50512 * *$ & 0.19228 & 0.19243 & 0.10787 & $0.14862 *$ & -0.00664 & -0.00246 \\
\hline$\beta_{\mathrm{S} 5}$ & $-0.32561 *$ & $-0.31132 *$ & -0.20545 & 0.10335 & -0.05476 & 0.15701 & 0.15894 \\
\hline$\gamma_{\mathrm{F} 1}$ & -0.10171 & -0.16171 & -0.08523 & -0.08508 & $-0.12387 * *$ & $0.22555^{*}$ & 0.16481 \\
\hline$\gamma_{F 2}$ & 0.04836 & 0.07645 & 0.21881 & $-0.31548 * *$ & -0.02595 & -0.02557 & 0.08449 \\
\hline$\gamma_{F 3}$ & -0.15247 & -0.01885 & $-0.01435 * *$ & -0.06837 & $0.01545^{*}$ & -0.04081 & 0.00479 \\
\hline$\gamma_{F 4}$ & $-0.42778^{*}$ & -0.12553 & -0.13059 & -0.01858 & -0.10056 & 0.04695 & 0.04648 \\
\hline$\gamma_{F 5}$ & 0.27177 & $0.2698^{*}$ & 0.17751 & -0.13055 & 0.10731 & -0.1385 & -0.1397 \\
\hline $\mathbf{R}^{2}$ & 0.0246 & 0.0201 & 0.0213 & 0.0285 & 0.0319 & 0.0084 & 0.0094 \\
\hline
\end{tabular}




\section{b) Futures prices}

\begin{tabular}{|c|c|c|c|c|c|c|c|}
\hline & \multicolumn{3}{|c|}{ Nifty } & \multicolumn{2}{|c|}{ Gold } & \multicolumn{2}{|c|}{ Soybean } \\
\hline & Future 1 & Future 2 & Future 3 & Future 1 & Future 2 & Future 1 & Future 2 \\
\hline$\alpha$ & 0.12091 & 0.10755 & 0.09914 & 0.05415 & 0.05605 & 0.02916 & 0.03014 \\
\hline$\beta_{\mathrm{F} 1}$ & $-0.4732 * *$ & -0.5627 & $-0.492 * *$ & -0.53844 & $-0.4942 * *$ & $0.22818^{*}$ & $0.18973 *$ \\
\hline$\beta_{\mathrm{F} 2}$ & -0.0285 & -0.05761 & 0.06083 & -0.40597 & $-0.3183 * *$ & 0.00498 & 0.11157 \\
\hline$\beta_{\mathrm{F} 3}$ & -0.19424 & -0.05445 & -0.09935 & -0.22715 & $-0.1462 * *$ & -0.00003 & 0.03671 \\
\hline$\beta_{\mathrm{F} 4}$ & $-0.4963 * *$ & -0.20183 & -0.2154 & -0.0619 & -0.13343 & 0.02607 & 0.03589 \\
\hline$\beta_{\mathrm{F} 5}$ & $0.33615^{*}$ & 0.34771 & $0.2572 * *$ & -0.17291 & $0.04439 *$ & -0.13979 & -0.08613 \\
\hline$\gamma_{\mathrm{s} 1}$ & $0.4955^{* *}$ & 0.58919 & $0.51681^{* *}$ & 0.6106 & $0.63558 * *$ & $-0.23662^{*}$ & -0.20014 \\
\hline$\gamma_{\mathrm{S} 2}$ & -0.06068 & -0.04133 & -0.14814 & 0.45884 & $0.39217 * *$ & -0.00376 & -0.11967 \\
\hline$\gamma_{\mathrm{s3}}$ & 0.14156 & -0.00243 & 0.03812 & 0.24972 & $0.17249 * *$ & -0.00964 & -0.04245 \\
\hline$\gamma_{\mathrm{S} 4}$ & $0.57068^{* *}$ & 0.27239 & 0.27647 & 0.16595 & $0.19705^{* *}$ & 0.01516 & 0.00659 \\
\hline$\gamma_{\mathrm{S5}}$ & $-0.4091 * *$ & -0.40625 & $-0.3009 * *$ & 0.12147 & 0.01591 & 0.1641 & 0.11441 \\
\hline $\mathbf{R}^{2}$ & 0.0301 & 0.0296 & 0.0332 & 0.084 & 0.2229 & 0.0073 & 0.0089 \\
\hline
\end{tabular}

$* *(*)$ denotes significance of estimates at $5 \%(10 \%)$ level

Table 4: Estimation of hedge ratio and hedging effectiveness

\begin{tabular}{|l|c|c|c|c|c|c|c|}
\hline & \multicolumn{3}{|c|}{ Nifty } & \multicolumn{2}{c|}{ Gold } & \multicolumn{2}{c|}{ Soybean } \\
\hline & Future 1 & Future 2 & Future 3 & Future 1 & Future 2 & Future 1 & Future 2 \\
\hline Covariance( $\left.\boldsymbol{\varepsilon}_{\mathbf{F}}, \boldsymbol{\varepsilon}_{\mathbf{S}}\right)$ & 1.955675 & 1.964752 & 1.927051 & 0.626340 & 0.446827 & 0.572247 & 0.562553 \\
\hline Variance $\left.\mathbf{(}_{\mathbf{F}}\right)$ & 2.136124 & 2.155891 & 2.105059 & 0.643147 & 0.505961 & 0.616320 & 0.622840 \\
\hline Hedge Ratio & 0.915525 & 0.911341 & 0.915438 & 0.973868 & 0.883125 & 0.928490 & 0.903207 \\
\hline Variance $\left(\boldsymbol{\varepsilon}_{\mathbf{S}}\right)$ & 1.840382 & 1.848928 & 1.846569 & 0.720482 & 0.717998 & 0.574066 & 0.573491 \\
\hline Variance(H) & 0.049913 & 0.058369 & 0.082473 & 0.110509 & 0.323394 & 0.042741 & 0.065389 \\
\hline Variance(U) & 1.840382 & 1.848928 & 1.846569 & 0.720482 & 0.717998 & 0.574066 & 0.573491 \\
\hline $\begin{array}{l}\text { Hedging } \\
\text { Effectiveness, E }\end{array}$ & 0.972879 & 0.968431 & 0.955337 & 0.846618 & 0.549590 & 0.925547 & 0.885981 \\
\hline
\end{tabular}

Hedge ratio calculated from VAR model are higher and perform better than OLS estimates in reducing variance. Hedge ratio estimated through VAR model increased from 0.71 (OLS estimate) to 0.88 in case of Gold Futures 2. For the same futures, hedging effectiveness also increase from $47 \%$, in case of OLS, to $55 \%$. Improvement is also observed for other futures contracts.

\subsubsection{VECM estimates}

Using the same approach as in case of VAR model, errors are estimated and hedging effectiveness and hedge ratio are calculated for VECM model. Results of the equation [7] are presented in Table 5. Table 6 illustrates the estimates of hedge ratio and hedging effectiveness of futures contracts. 
Table 5: Estimates of VECM model

\section{a) Spot prices}

\begin{tabular}{|c|c|c|c|c|c|c|c|}
\hline & \multicolumn{3}{|c|}{ Nifty } & \multicolumn{2}{|c|}{ Gold } & \multicolumn{2}{|c|}{ Soybean } \\
\hline & Future 1 & Future 2 & Future 3 & Future 1 & Future 2 & Future 1 & Future 2 \\
\hline$\alpha$ & -0.00001 & -0.00149 & -0.00224 & -0.00532 & -0.00202 & -0.02532 & $-0.0408 * *$ \\
\hline $\boldsymbol{\beta}_{\mathrm{S}}$ & 0.05004 & 0.08557 & 0.09408 & 0.20126 & 0.10592 & -0.09951 & -0.07257 \\
\hline$\beta_{\mathrm{S} 2}$ & $0.46701 * *$ & $0.55394 * *$ & $0.42326^{* *}$ & $-0.3692 * *$ & -0.05038 & $0.28075^{* *}$ & $-0.1840 * *$ \\
\hline$\beta_{\mathrm{S} 3}$ & 0.05165 & 0.08965 & -0.02764 & -0.01643 & 0.05927 & $-0.19247 *$ & $-0.14661 *$ \\
\hline$\beta_{\mathrm{S} 4}$ & $0.05019 * *$ & 0.18872 & $0.32751^{*}$ & -0.06997 & -0.02164 & -0.04046 & -0.03318 \\
\hline$\beta_{\mathrm{S5}}$ & 0.54985 & $0.68071 * *$ & $0.64861 * *$ & 0.01489 & $0.17944 * *$ & $-0.2038^{* *}$ & -0.08434 \\
\hline$\gamma_{F}$ & -0.04993 & -0.08532 & -0.09376 & -0.20043 & -0.10544 & 0.10293 & 0.07811 \\
\hline$\gamma_{F 2}$ & $-0.36327 *$ & $-0.4412 * *$ & $-0.32379 *$ & $0.40538 * *$ & 0.05899 & $0.28704 * *$ & $0.1867 * *$ \\
\hline$\gamma_{F 3}$ & -0.12872 & -0.16659 & -0.04819 & 0.04557 & -0.01813 & 0.15622 & 0.10214 \\
\hline$\gamma_{F 4}$ & -0.07455 & -0.20544 & -0.33422 & 0.03953 & -0.00939 & 0.05576 & 0.04407 \\
\hline$\gamma_{F 5}$ & $-0.4718 * *$ & $-0.5920 * *$ & $-0.5729 * *$ & -0.02166 & $-0.2352 * *$ & $0.24222 * *$ & 0.1148 \\
\hline $\mathbf{R}^{2}$ & 0.0243 & 0.0318 & 0.0358 & 0.0258 & 0.0307 & 0.0384 & 0.0385 \\
\hline
\end{tabular}

$* *(*)$ denotes significance of estimates at $5 \%(10 \%)$ level

\section{b) Futures prices}

\begin{tabular}{|c|c|c|c|c|c|c|c|}
\hline & \multicolumn{3}{|c|}{ Nifty } & \multicolumn{2}{|c|}{ Gold } & \multicolumn{2}{|c|}{ Soybean } \\
\hline & Future 1 & Future 2 & Future 3 & Future 1 & Future 2 & Future 1 & Future 2 \\
\hline$\alpha$ & -0.003 & -0.00339 & -0.00415 & -0.00749 & -0.00367 & -0.00949 & -0.0205 \\
\hline$\beta_{F}$ & $-0.2064 * *$ & $-0.1512^{* *}$ & -0.14817 & -0.2663 & -0.15307 & 0.04014 & 0.03983 \\
\hline$\beta_{\mathrm{F} 2}$ & -0.6994 & -0.90632 & $-0.8538 * *$ & $-0.27776^{*}$ & $-0.4906^{* *}$ & $0.28336^{* *}$ & $0.18402 * *$ \\
\hline$\beta_{\mathrm{F} 3}$ & -0.26479 & -0.36496 & $-0.32946^{*}$ & -0.25836 & $-0.3937 * *$ & 0.15243 & 0.0755 \\
\hline$\beta_{\mathrm{F} 4}$ & -0.16024 & $-0.2986^{* *}$ & $-0.5275^{* *}$ & $-0.2692 *$ & $-0.2634 * *$ & 0.01391 & 0.03344 \\
\hline$\beta_{\mathrm{F} 5}$ & $-0.6037 * *$ & -0.76175 & $-0.7618 * *$ & -0.1454 & $"-0.259 * *$ & 0.16678 & 0.07962 \\
\hline$\gamma_{\mathrm{S}}$ & 0.20687 & 0.15161 & 0.14868 & 0.26741 & 0.15376 & -0.03881 & -0.03701 \\
\hline$\gamma_{\mathrm{S2}}$ & $0.79099 * *$ & $1.01436^{* *}$ & $0.95749 * *$ & $0.3334 * *$ & $0.55949 * *$ & $-0.2917 * *$ & $-0.1886^{* *}$ \\
\hline$\gamma_{\mathrm{S3}}$ & 0.19292 & 0.29177 & $0.26873 * *$ & $0.30404 *$ & $0.43944 * *$ & -0.18824 & -0.12756 \\
\hline$\gamma_{\mathrm{S} 4}$ & 0.1372 & 0.28757 & $0.52992 * *$ & 0.24972 & $0.261 * *$ & -0.00141 & -0.03412 \\
\hline$\gamma_{\mathrm{S} 5}$ & $0.69213 * *$ & $0.86826^{* *}$ & $0.855 * *$ & 0.14775 & $0.26046^{* *}$ & $-0.1378 * *$ & -0.06379 \\
\hline $\mathbf{R}^{2}$ & 0.034 & 0.0475 & 0.0604 & 0.0551 & 0.1828 & 0.0201 & 0.0181 \\
\hline
\end{tabular}

$* *(*)$ denotes significance of estimates at $5 \%(10 \%)$ level

Although VECM model does not consider the conditional covariance structure of spot and futures price, it is supposed to be best specified model for the estimations of constant hedge ratio and hedging effectiveness because it factors in any long term co-integration between spot and futures prices. It has been found that in-sample performance of VECM model provides better variance reduction that VAR and OLS model. OLS seems to be least efficient. Our results are consistent with the findings of Ghosh (1993). 
Table 6: Estimation of hedge ratio and hedging effectiveness

\begin{tabular}{|c|c|c|c|c|c|c|c|}
\hline & \multicolumn{3}{|c|}{ Nifty } & \multicolumn{2}{|c|}{ Gold } & \multicolumn{2}{|c|}{ Soybean } \\
\hline & Future 1 & Future 2 & Future 3 & Future 1 & Future 2 & Future 1 & Future 2 \\
\hline $\begin{array}{l}\text { Covariance }\left(\varepsilon_{\mathrm{F}},\right. \\
\varepsilon_{\mathrm{S})}\end{array}$ & 0.00029897 & 0.00029729 & 0.00029241 & 0.00010045 & 0.00007981 & 0.00011045 & 0.00010678 \\
\hline Variance $\left(\varepsilon_{F}\right)$ & 0.00032731 & 0.00032633 & 0.00032054 & 0.00010070 & 0.00008141 & 0.00012089 & 0.00012563 \\
\hline Hedge Ratio & 0.91341151 & 0.91101612 & 0.91224194 & 0.99757688 & 0.98027566 & 0.91357658 & 0.85001364 \\
\hline Variance $\left(\varepsilon_{\mathrm{s}}\right)$ & 0.00027996 & 0.00027782 & 0.00027665 & 0.00011035 & 0.00010979 & 0.00011397 & 0.00011395 \\
\hline Variance(H) & 0.00000688 & 0.00000698 & 0.00000991 & 0.00001013 & 0.00003155 & 0.00001307 & 0.00002318 \\
\hline Variance(U) & 0.00027996 & 0.00027782 & 0.00027665 & 0.00011035 & 0.00010979 & 0.00011397 & 0.00011395 \\
\hline $\begin{array}{l}\text { Hedging } \\
\text { Effectiveness, } \\
\text { E }\end{array}$ & 0.97542167 & 0.97487147 & 0.96418452 & 0.90816098 & 0.71260213 & 0.88532617 & 0.79655091 \\
\hline
\end{tabular}

\subsubsection{VAR-MGARCH MODEL}

VAR-MGARCH model is used to modify the estimation of hedge ratio for time varying volatility and to incorporate non-linearity in the mean equation. Errors of the VAR and VECM models are analyzed for presence of "ARCH effect" and it was found that the errors have time varying volatility. Errors obtained from the VAR and VECM model are shown in Appendix $1^{10}$. VAR models with bivariate Diagonal GARCH $(1,1)$ are used and results are presented in Table 7.

Table 7: GARCH estimates of the VAR-MGARCH $(1,1)$ model

\begin{tabular}{|c|c|c|c|c|c|}
\hline & \multicolumn{3}{|c|}{ Nifty } & \multicolumn{2}{|c|}{ Gold } \\
\hline & Future 1 & Future 2 & Future 3 & Future 1 & Future 2 \\
\hline $\mathrm{C}_{\mathrm{ss}}$ & $1.88922 * *$ & $1.89082 * *$ & $1.74192 * *$ & $0.67245^{* *} *$ & $0.68831 * *$ \\
\hline $\mathrm{C}_{\text {sf }}$ & $2.01818 * *$ & $2.00367 * *$ & $1.85564 * *$ & $0.58417 * *$ & $0.43065 * *$ \\
\hline $\mathrm{C}_{\mathrm{ff}}$ & $2.19812 * *$ & $2.17527 * *$ & $2.20075^{* *} *$ & $0.53565 * *$ & $0.47647 * *$ \\
\hline$\alpha_{11}$ & $0.0014 * *$ & $0.14607 * *$ & $-0.43134 * *$ & $0.69091 * *$ & $0.32432 * *$ \\
\hline$\alpha_{22}$ & $-0.00147 * *$ & $0.15032 * *$ & $-0.42755 * *$ & $0.55232 * *$ & $0.26384 * *$ \\
\hline$\alpha_{33}$ & $0.00312 * *$ & $0.16131 * *$ & $-0.39683^{* *}$ & $0.45838 * *$ & $0.32959 * *$ \\
\hline$\beta_{11}$ & $-0.00523 * *$ & $0.02881 * *$ & $-0.05434 * *$ & $0.00961 * *$ & $-0.01095 * *$ \\
\hline$\beta_{22}$ & $0.01247 * *$ & $0.00045 * *$ & $-0.02726 * *$ & $0.05161 * *$ & $0.01465 * *$ \\
\hline$\beta_{33}$ & $-0.00589 * *$ & $-0.03453 * *$ & $-0.05503 * *$ & $0.10733 * *$ & $-0.06218 * *$ \\
\hline
\end{tabular}

$* *(*)$ denotes significance of estimates at $5 \%(10 \%)$ level

\footnotetext{
${ }^{10}$ Results of ARCH text on residuals, obtained from VAR and VECM, can be obtained from authors on request.
} 
Time varying hedge ratio for Nifty and Gold futures has been estimated using error structure and GARCH $(1,1)$ parameters obtained from equation [8]. Time varying hedge ratio estimated from constant conditional correlation and time varying covariance structure of spot and futures prices are shown in Figure 2. Statistical properties of Hedge ratio obtained from M-GARCH model for Nifty and Gold futures are given in table 8 .

Table 8: Statistical properties of dynamic hedge ratio fromVAR-MGARCH model

\begin{tabular}{|l|l|l|l|c|c|}
\hline & Hedge Ratio & Min & Max & \multicolumn{1}{l|}{ Mean } & \multicolumn{1}{l|}{ SD } \\
\hline \multirow{3}{*}{ Nifty } & Future 1 & 0.79112 & 0.935219 & 0.931028 & 0.011024 \\
\cline { 2 - 6 } & Future 2 & 0.710722 & 1.153131 & 0.9476 & 0.027281 \\
\cline { 2 - 6 } & Future 3 & -9.039 & 9.616319 & 0.842709 & 0.655289 \\
\hline \multirow{3}{*}{ Gold } & Future 1 & -0.56527 & 1.884075 & 1.028782 & 0.141592 \\
\cline { 2 - 6 } & Future 2 & -0.46332 & 3.213549 & 0.951656 & 0.201246 \\
\hline
\end{tabular}

The mean hedge ratio estimated from the time-varying conditional variance and covariance between spot and futures returns are higher than other methods (except Nifty Futures 3). The average optimal hedge ratio for Nifty Futures 1, Futures 2 and Futures 3 are $0.9310,0.9476$ and 0.8427 respectively. For Gold Futures 1 and Futures 2, this ratio is 1.0288 and 0.9516 respectively. It is found that as we move to distant futures the variation in hedge ratio increases $(0.011024$ to 0.655289 in case of Nifty and 0.141592 to 0.201246 in case of Gold).

Since the dynamics hedge ratio are less stable and having pronounced fluctuations, the hedger has to adjust their futures positions more often. The negative hedge ratio reflects the fact that spot and futures prices may move in opposite direction (negative covariance) in short run (Tong, 1996). It requires the hedger to go long in futures market to hedge the long spot position. 


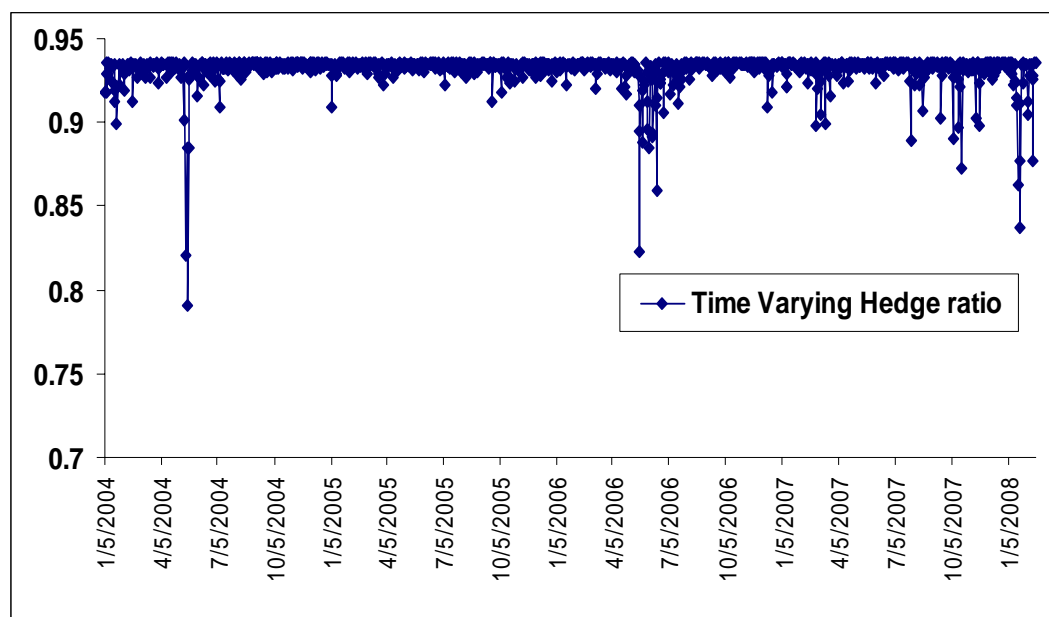

a) Nifty Future 1

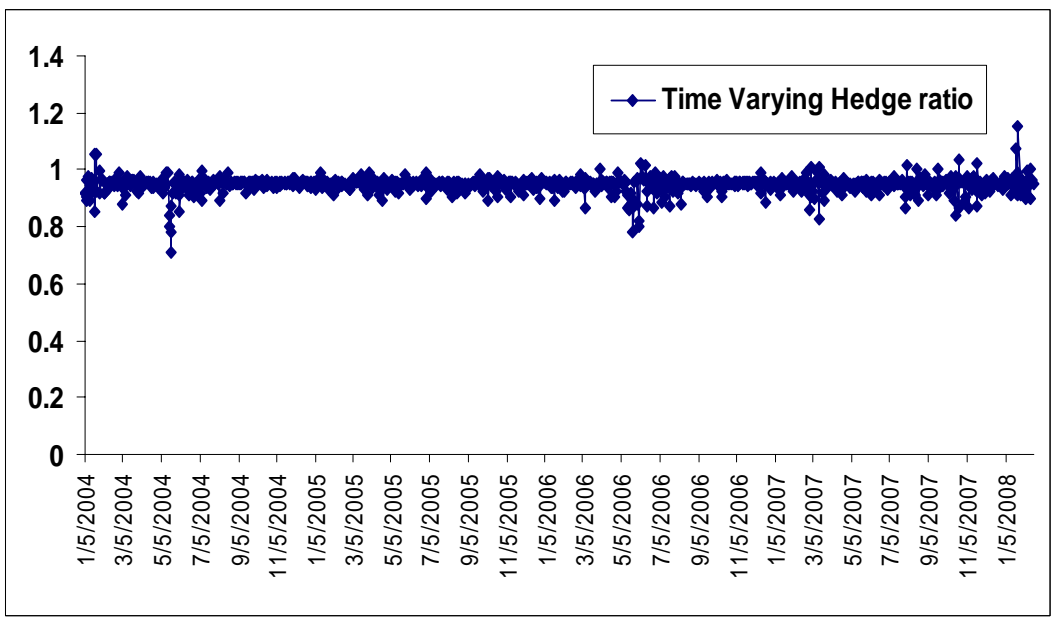

b) Nifty Future 2

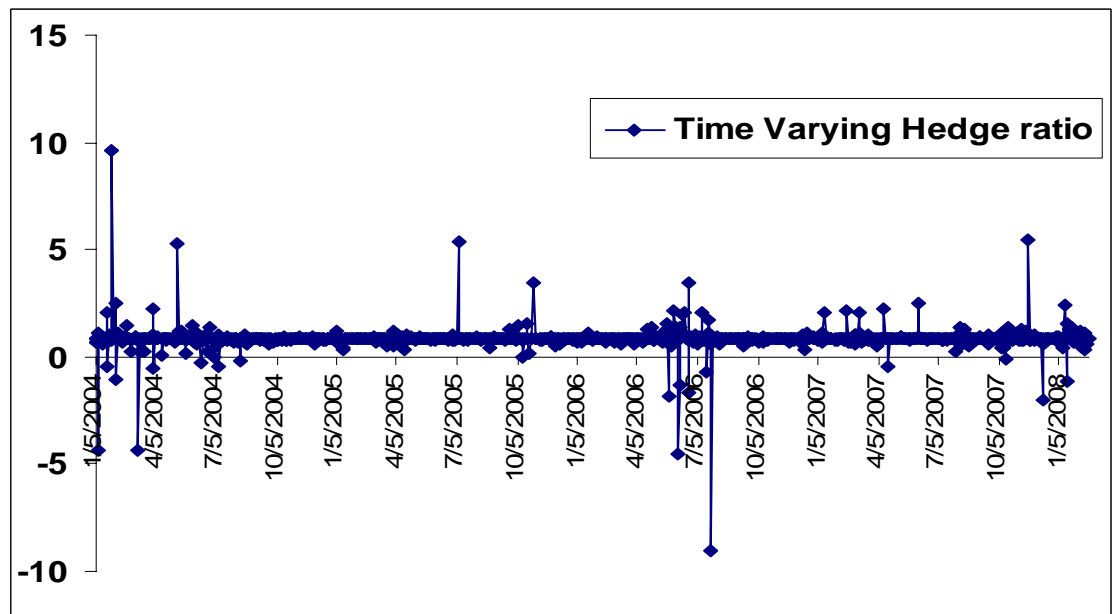

c) Nifty Future 3 


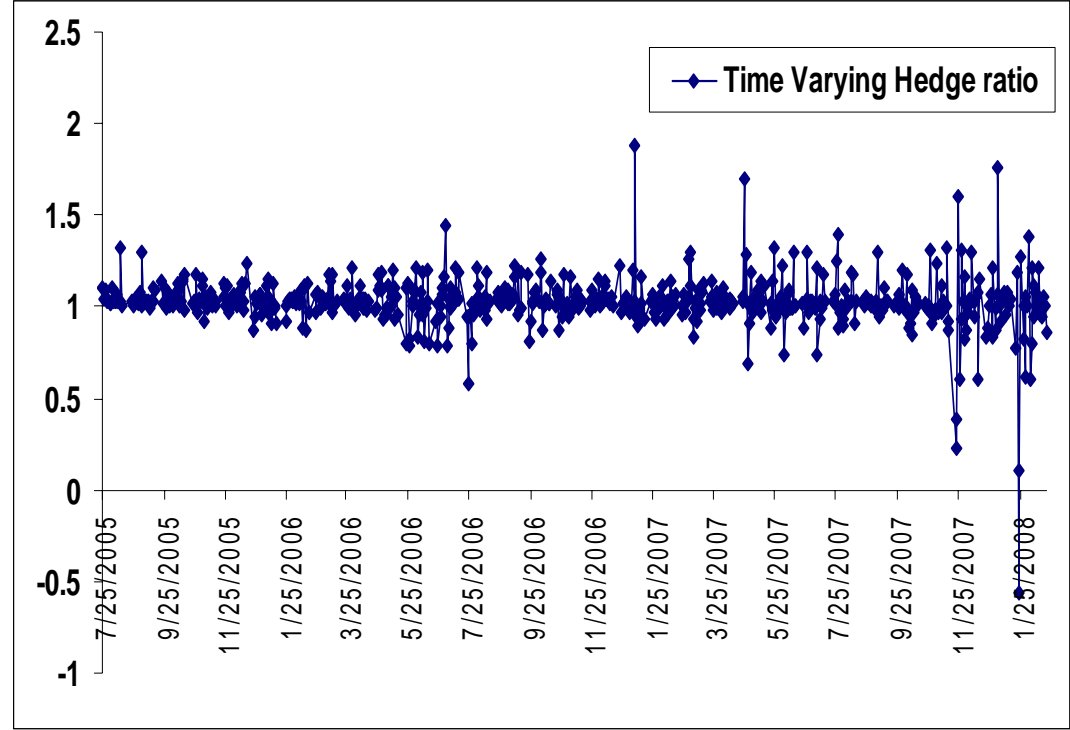

d) Gold Future 1

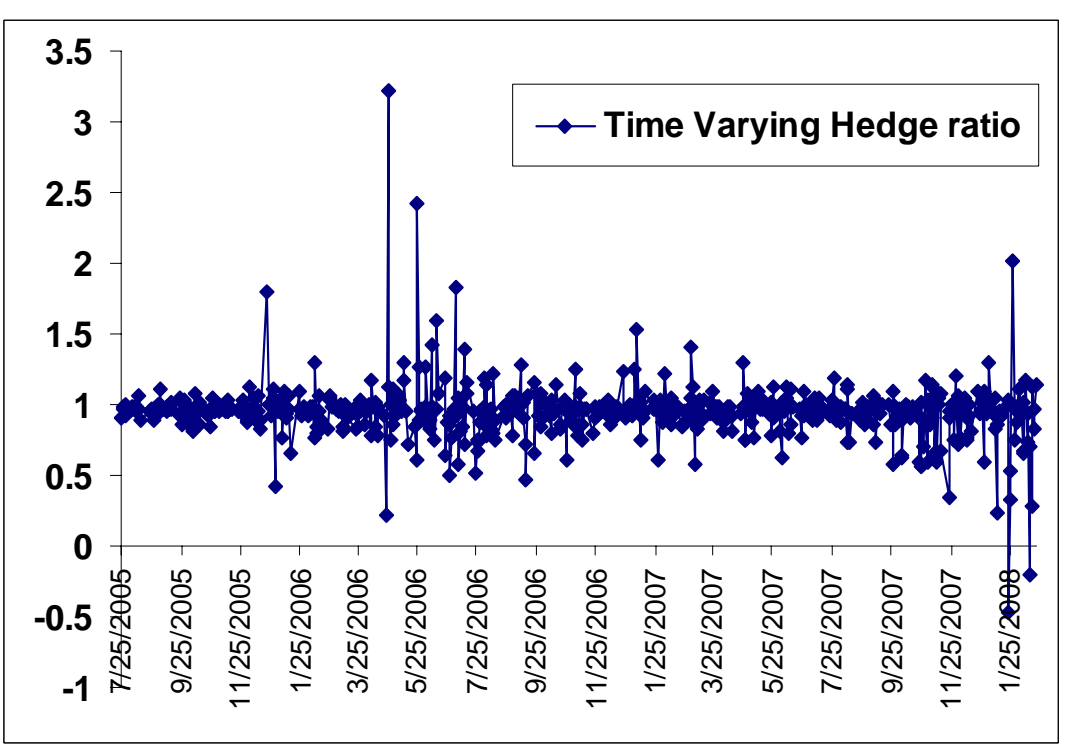

e) Gold Future 2

Figure 2: Estimates of time varying hedge ratio from VAR-MGARCH model. 
Constant hedge ratio obtained from OLS, VAR, VECM and average of time varying hedge ratio obtained from VAR-MGARCH model is compared in Table $9 \& 10$. Our results show that hedge ratio calculated from VAR-MGARCH $(1,1)$ are higher and provide greater variance reduction than other models. Similar results were reported in the previous studies of Myers (1991), Baillie and Myers (1991) and Park and Switzer $(1995 \mathrm{a}, \mathrm{b})$ in the US financial and commodity markets. In case of constant hedge ratio estimation, VECM performs better than OLS and VAR models. Similar results were found by Ghosh (1993).

Table 9: In-sample comparison of optimal hedge ratio estimates by different models

\begin{tabular}{|c|c|c|c|c|c|c|c|}
\hline & \multicolumn{3}{|c|}{ Nifty } & \multicolumn{2}{c|}{ Gold } & \multicolumn{2}{c|}{ Soybean } \\
\hline & Future 1 & Future 2 & Future 3 & Future 1 & Future 2 & Future 1 & Future 2 \\
\hline OLS & 0.91181 & 0.90519 & 0.908360 & 0.92387 & 0.73613 & 0.93092 & 0.90329 \\
\hline VAR & 0.91552 & 0.91134 & 0.915438 & 0.97387 & 0.88312 & 0.92849 & 0.903207 \\
\hline VECM & 0.913411 & 0.91102 & 0.912242 & 0.99758 & 0.980275 & 0.913576 & 0.850013 \\
\hline VAR-MGARCH & 0.93103 & 0.9476 & 0.84271 & 1.02878 & 0.95165 & -- & -- \\
\hline
\end{tabular}

Table 10: In-sample comparison of optimal hedging effectiveness estimates by different models

\begin{tabular}{|c|c|c|c|c|c|c|c|}
\hline & \multicolumn{3}{|c|}{ Nifty } & \multicolumn{2}{c|}{ Gold } & \multicolumn{2}{c|}{ Soybean } \\
\hline & Future 1 & Future 2 & Future 3 & Future 1 & Future 2 & Future 1 & Future 2 \\
\hline OLS & 0.9696 & 0.9641 & 0.9483 & 0.8076 & 0.4749 & 0.9264 & 0.8856 \\
\hline VAR & 0.972879 & 0.968431 & 0.955337 & 0.846618 & 0.54959 & 0.925547 & 0.88598 \\
\hline VECM & 0.9754217 & 0.9748715 & 0.964184 & 0.908161 & 0.712602 & 0.8853262 & 0.79655 \\
\hline VAR-MGARCH & 1.009626 & 0.977068 & 0.911171 & 0.892781 & 0.597047 & & \\
\hline
\end{tabular}

\subsection{OUT-OF-THE-SAMPLE RESULTS}

Brook and Chong (2001) suggested that out-of-the-sample evaluation of models is more appropriate because traders are more concerned with future performance. This is particularly true for comparing performance of a model using dynamic hedge ratio. Hence, data for the period of $21^{\text {st }}$ February 2008 to $8^{\text {th }}$ May 2008 has been used for out of sample analysis for nifty futures. Similarly, for Gold and Soybean, data for the period of $21^{\text {st }}$ February 2008 to $8^{\text {th }}$ May 2008 and $1^{\text {st }}$ January 2008 to $8^{\text {th }}$ May 2008 has been used 
for out-of-sample analysis respectively. For OLS, VAR and VECM models, the estimated hedge ratios from the estimation period are used for testing their out-of the-sample performance. For bivariate GARCH, we estimate one-period-ahead estimates of conditional variance and covariance of spot and futures prices from parameters estimated from estimation period. Out of sample estimates of hedge ratio and their statistical properties for VAR-MGARCH $(1,1)$ are presented in Table 11. Figure 3 illustrates the comparison of out-of-sample estimates of hedge ratio from GARCH model and in-sample estimates of OLS, VAR and VEC model.

Table 11 Out of sample estimates of hedge ratio and their statistical properties

\begin{tabular}{|c|c|c|c|c|c|}
\hline & Hedge Raio & Min & Max & Mean & SD \\
\hline \multirow{3}{*}{ Nifty } & Future 1 & 0.872641 & 0.935207 & 0.929749 & 0.012059 \\
\cline { 2 - 6 } & Future 2 & -0.20942 & 1.392218 & 0.730338 & 0.321048 \\
\cline { 2 - 6 } & Future 3 & -6.21891 & 2.526035 & 0.524149 & 1.452091 \\
\hline \multirow{2}{*}{ Gold } & Future 1 & 0.211217 & 1.953885 & 0.989963 & 0.241402 \\
\cline { 2 - 6 } & Future 2 & 1.099314 & 16.79628 & 3.456777 & 2.652792 \\
\hline
\end{tabular}

Out-of-sample estimates of dynamic hedge ratio in Nifty and Gold futures have higher variability than in-sample estimates. As observed in in-sample results, variation in the dynamic hedge ratio of distant month futures is more than in near month futures. Out-of sample performance of hedging effectiveness calculated from OLS, VAR, and VECM model are estimated and given in Table 12 to 14 .

Table 12: OLS model

\begin{tabular}{|c|c|c|c|c|c|c|c|}
\hline & \multicolumn{3}{|c|}{ Nifty } & \multicolumn{2}{|c|}{ Gold } & \multicolumn{2}{|c|}{ Soybean } \\
\hline & Future 1 & Future 2 & Future 3 & Future 1 & Future 2 & Future 1 & Future 2 \\
\hline $\begin{array}{l}\text { Covariance }\left(\varepsilon_{F},\right. \\
\left.\varepsilon_{S}\right)\end{array}$ & 2.497725 & 2.810920 & 1.855876 & 0.645968 & 0.417951 & 2.127770144 & 2.100567881 \\
\hline Variance $\left(\varepsilon_{F}\right)$ & 2.728433 & 5.152587 & 4.004857 & 0.978732 & 3.410071 & 2.307298235 & 2.300496681 \\
\hline $\begin{array}{l}\text { Hedge Ratio, } \\
\text { H }\end{array}$ & 0.911810 & 0.905190 & 0.908360 & 0.92387 & 0.73613 & 0.93092 & 0.90329 \\
\hline Variance $\left(\varepsilon_{S}\right)$ & 2.452104 & 2.452104 & 2.452104 & 1.08058933 & 1.08058933 & 2.094264 & 2.094264 \\
\hline $\begin{array}{l}\text { Variance } \\
\text { (Hedged) }\end{array}$ & 0.165615 & 1.585141 & 2.384976 & 0.726082 & 3.107916 & 0.132059 & 0.248292 \\
\hline $\begin{array}{l}\text { Variance } \\
\text { (Unhedged) }\end{array}$ & 2.452104 & 2.452104 & 2.452104 & 1.08058933 & 1.08058933 & 2.094264 & 2.094264 \\
\hline $\begin{array}{l}\text { Hedging } \\
\text { Effectiveness, } \\
\text { E }\end{array}$ & 0.932460 & 0.353559 & 0.027376 & 0.328069 & -1.876130 & 0.936942 & 0.881442 \\
\hline
\end{tabular}



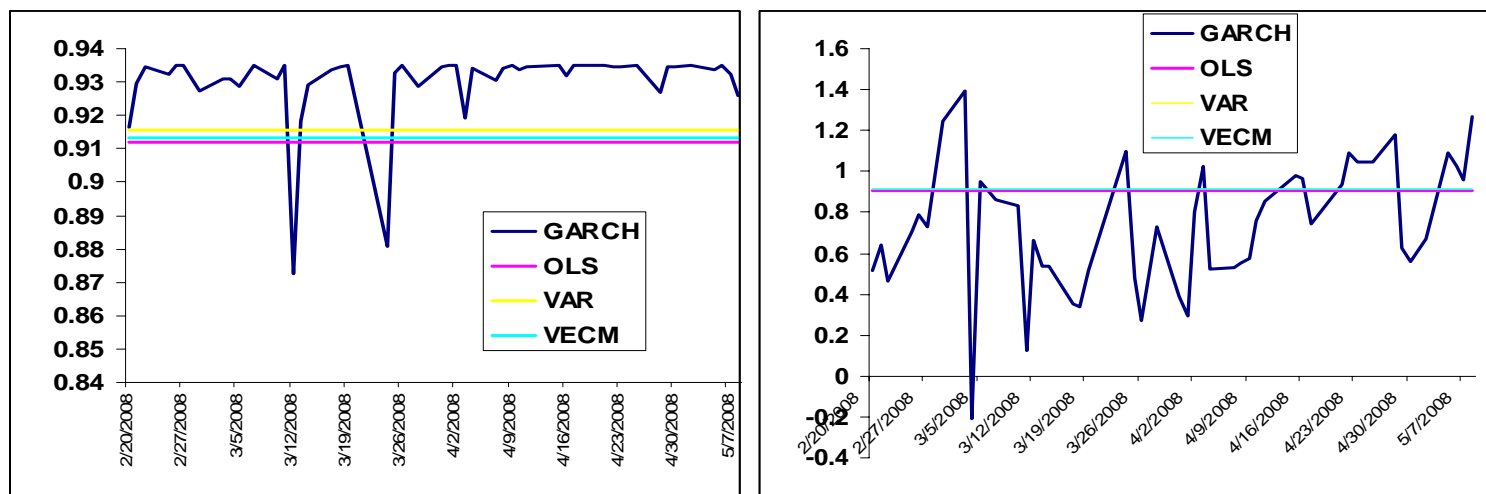

a) Nifty Future 1

b) Nifty Future 2

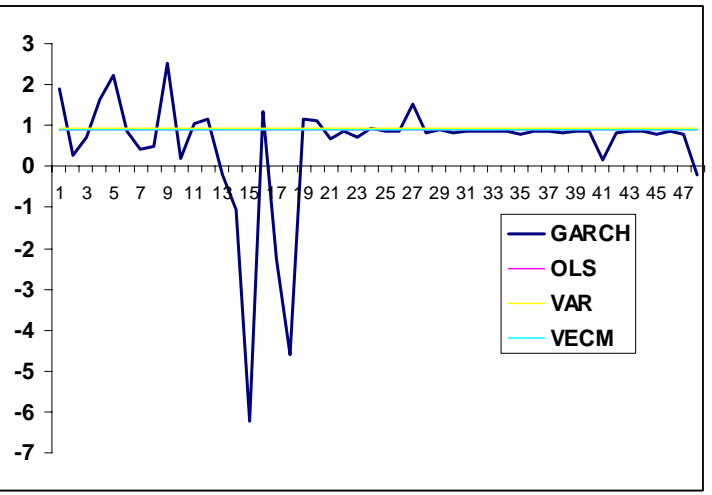

c) Nifty Future 3

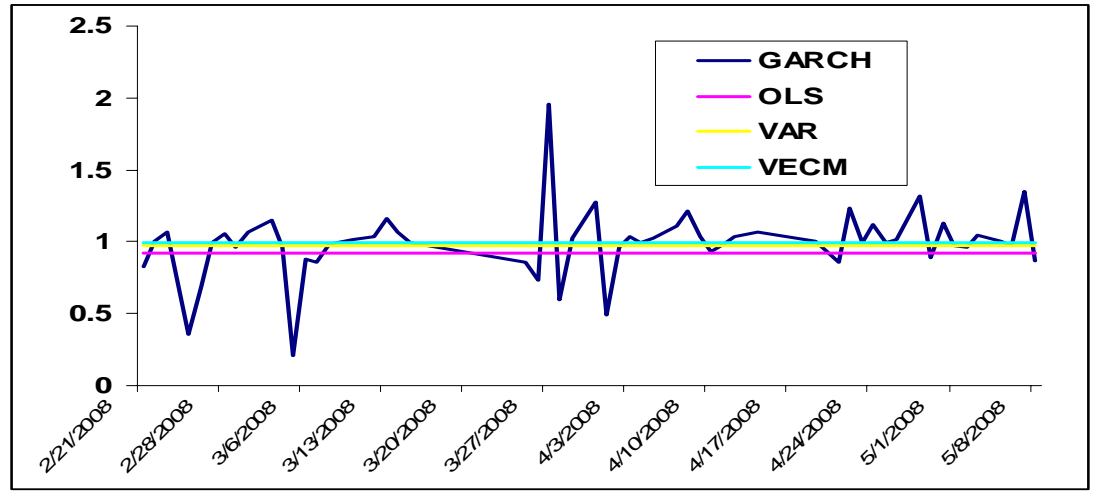

d) Gold Future 1

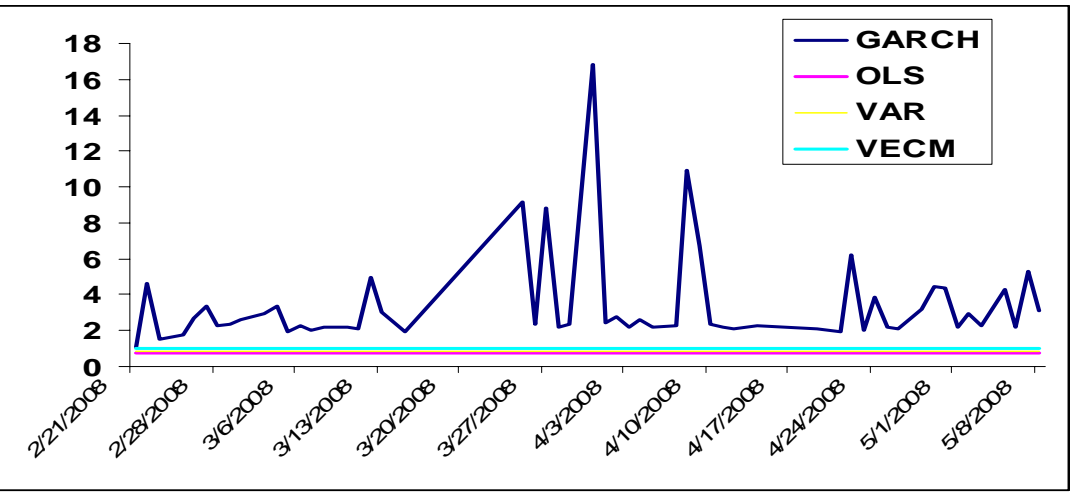

e) Gold Future 2

Figure 3: Out-of-sample comparison of hedge ratio 
Table 13: VAR model

\begin{tabular}{|l|c|c|c|c|c|c|c|}
\hline & \multicolumn{3}{|c|}{ Nifty } & \multicolumn{2}{c|}{ Gold } & \multicolumn{2}{c|}{ Soybean } \\
\hline & Future 1 & Future 2 & Future 3 & Future 1 & Future 2 & Future 1 & Future 2 \\
\hline $\begin{array}{l}\text { Covariance( } \boldsymbol{\varepsilon}_{\mathrm{F}}, \\
\left.\boldsymbol{\varepsilon}_{\mathbf{S}}\right)\end{array}$ & 2.695598 & 2.459859 & 2.223129 & 0.621495702 & 0.767535287 & 2.101569844 & 2.088639265 \\
\hline Variance $\left(\boldsymbol{\varepsilon}_{\mathrm{F}}\right)$ & 2.868049 & 3.841825 & 4.037208 & 0.647550447 & 3.492637982 & 2.292162006 & 2.297210329 \\
\hline $\begin{array}{l}\text { Hedge Ratio, } \\
\text { H }\end{array}$ & 0.915525 & 0.911341 & 0.915438 & 0.973868 & 0.883125 & 0.92849 & 0.903207 \\
\hline Variance $\left(\boldsymbol{\varepsilon}_{\mathbf{S}}\right)$ & 2.692616 & 2.460410 & 2.923080 & 1.086411499 & 1.241911142 & 2.060467463 & 2.08568957 \\
\hline $\begin{array}{l}\text { Variance } \\
\text { (Hedged) }\end{array}$ & 0.160799 & 1.167668 & 2.236094 & 0.490051 & 2.610194 & 0.133953 & 0.186767 \\
\hline $\begin{array}{l}\text { Variance } \\
\text { (Unhedged) }\end{array}$ & 2.692616 & 2.460410 & 2.923080 & 1.086411499 & 1.241911142 & 2.060467463 & 2.08568957 \\
\hline $\begin{array}{l}\text { Hedging } \\
\text { Effectiveness, } \\
\text { E }\end{array}$ & 0.940281 & 0.525417 & 0.235021 & 0.548927 & -1.101756 & 0.934989 & 0.910453 \\
\hline
\end{tabular}

Table 14: VECM Model

\begin{tabular}{|l|c|c|c|c|c|c|c|}
\hline & \multicolumn{3}{|c|}{ Nifty } & \multicolumn{2}{c|}{ Gold } & \multicolumn{3}{c|}{ Soybean } \\
\hline & Future 1 & Future 2 & Future 3 & Future 1 & Future 2 & Future 1 & Future 2 \\
\hline $\begin{array}{l}\text { Covariance } \\
\left(\boldsymbol{\varepsilon}_{\mathrm{F}}, \boldsymbol{\varepsilon}_{\mathbf{S}}\right)\end{array}$ & 0.0002501 & 0.0007967 & 0.0004581 & $6.63211 \mathrm{E}-05$ & $-3.89 \mathrm{E}-06$ & 0.0002335 & 0.0002289 \\
\hline Variance $\left.\boldsymbol{(}_{\mathrm{F}}\right)$ & 0.000278 & 0.0013100 & 0.0008337 & $9.34037 \mathrm{E}-05$ & 0.000346896 & 0.0002415 & 0.0002106 \\
\hline $\begin{array}{l}\text { Hedge Ratio, } \\
\text { H }\end{array}$ & 0.913411 & 0.911016 & 0.9122419 & 0.99757688 & 0.98027566 & 0.913576 & 0.850013 \\
\hline Variance $\left(\boldsymbol{\varepsilon}_{\mathbf{S}}\right)$ & 0.00024 & 0.000590 & 0.000426 & 0.000113105 & 0.000111004 & 0.0003519 & 0.0002116 \\
\hline $\begin{array}{l}\text { Variance } \\
\text { (Hedged) }\end{array}$ & 0.000020 & 0.000225 & 0.000284 & 0.000074 & 0.000452 & 0.000127 & -0.000025 \\
\hline $\begin{array}{l}\text { Variance } \\
\text { (Unhedged) }\end{array}$ & 0.000245 & 0.000590 & 0.000426 & 0.000113105 & 0.000111004 & 0.0003519 & 0.0002116 \\
\hline $\begin{array}{l}\text { Hedging } \\
\text { Effectiveness, } \\
\text { E }\end{array}$ & 0.917644 & 0.617806 & 0.333268 & 0.348076 & -3.071775 & 0.639576 & 1.119445 \\
\hline
\end{tabular}

Out-of- the sample, among constant hedge models, OLS and VAR models perform better than VECM for near month futures. However, for distant month futures VECM perform better than OLS and $\mathrm{VAR}^{11}$ models. We also compare the out-of- the sample hedging effectiveness of constant hedge ratio models and dynamic hedge ratio models, bivariate GARCH. These comparisons are presented in Table 15.

\footnotetext{
11 In case of Gold futures 2, we find negative hedge effectiveness estimated from all constant hedge models. This may be because of higher futures return variance.
} 
Table 15: Out-of-sample comparison of optimal hedging effectiveness of different models

\begin{tabular}{|c|c|c|c|c|c|c|c|}
\hline & \multicolumn{3}{|c|}{ Nifty } & \multicolumn{2}{c|}{ Gold } & \multicolumn{2}{c|}{ Soybean } \\
\hline & Future 1 & Future 2 & Future 3 & Future 1 & Future 2 & Future 1 & Future 2 \\
\hline OLS & 0.93246 & 0.353559 & 0.027376 & 0.32807 & -1.87613 & 0.936942 & 0.88144 \\
\hline VAR & 0.94028 & 0.525417 & 0.235021 & 0.54893 & -1.10175 & 0.934989 & 0.91045 \\
\hline VECM & 0.91764 & 0.617806 & 0.333268 & 0.34808 & -3.07177 & 0.639576 & 1.11945 \\
\hline VAR-MGARCH & 1.00710 & 0.752793 & 1.312628 & 0.787436 & 2.69272 & & \\
\hline
\end{tabular}

Across all futures contracts, dynamic hedge ratio model, bivariate GARCH, performs better than constant hedge ratio models in variance reduction. Similar results were found in studies of Myers (1991), Baillie and Myers (1991) Park and Switzer (1995) Kavussanos and Nomikos (2000), Yang (2001), and Floros and Vougas (2006). However, hedging strategy suggested by VAR-MGARCH model may requires frequent shift in hedging positions and would result in associated transaction costs.

\section{CONCLUSIONS}

In an emerging market like India, where stock and commodity markets are growing at a fast rate and derivatives have been introduced recently, it is important to evaluate the hedging effectiveness of derivatives. In the present paper, we report hedge ratios of Nifty, Gold and Soybean futures from four alternative modeling frameworks, an OLS-based model, a VAR model, a VECM model and a multivariate GARCH model. We compare the hedging effectiveness of the contacts using these models, ex post (in-sample) and ex ante (out-of-sample).

Our results show that futures and spots prices are found to be co-integrated in the long run. Among constant hedge ratio models, in most of the cases, VECM performs better than OLS and VAR models, which is consistent with previous findings of Ghosh (1993b). Time varying hedge ratio derived from VAR-MGARCH model provides highest variance reduction as compared to the other methods in both in-sample as well as out-of sample period for all contracts. This result is consistent with the results of Myers (1991), Baillie and Myers (1991), Park and Switzer (1995a,b), Lypny and Powella (1998), 
Kavussanos and Nomikos (2000), Yang (2001), and Floros and Vougas (2006). VARMGARCH hedge ratio, however, varies dramatically over time and calls for frequent changes in hedging positions. Transaction cost in implementing dynamic hedging using VAR-MGARCH may nullify some of the gains provided by it. Both stock market and commodity derivatives markets in India provide a reasonably high level of hedging effectiveness $(90 \%)$ and it can be said that derivatives markets in Indian context provide useful risk management tool for hedging and for portfolio diversification. 


\section{References}

Anderson, R. W., \& Danthine, J. P. (1981). Cross hedging. Journal of Political Economy, 81, 1182-1196.

Bailey, W., \& Chan, K. C. (1993). Macroeconomic influences and the variability of the commodity futures basis. Journal of Finance, 48, 555-573.

Baillie, R., \& Myers R. (1991). Bivariate GARCH estimation of the optimal commodity futures hedge. Journal of Applied Econometrics, 6, 109-124.

Benninga, S., Eldor, R., \& Zilcha, I. (1983). Optimal hedging in the futures market under price uncertainty. Economics Letters, 13, 141-145.

Benninga, S., Eldor, R., \& Zilcha, I. (1984). The optimal hedge ratio in unbiased futures market. Journal of Futures Market, 4, 155-159.

Bessembinder, H. J., Coughenour, P., \& Smoller, M. (1995). Mean reversion in equllibrium asset prices: evidence from the futures term structure. Journal of Finance, 50, 361-375.

Bhaduri, S. N., \& Durai, S. N. S. (2008) Optimal hedge ratio and hedging effectiveness of stock index futures: evidence from India. Macroeconomics and Finance in Emerging Market Economies, 1, 121-134.

Bollerslev, T., Chou, R. Y., \& Kroner, K. F. (1992). ARCH modeling in finance. Journal of Econometrics, 52, 5-59.

Bollerslev, T, Engle, R., \& Wooldridge, J. M. (1988). A Capital Asset Pricing Model with time Varying Covariances. Journal of Political Economy, 96, 116-131.

Bose, S. (2007). Understanding the Volatility Characteristics and Transmission Effects in the Indian Stock Index and Index Futures Market. Money and Finance, ICRA Bulletin, 139-162. 
Brooks, C., \& Chong, J. (2001). The cross-currency hedging performance of implied versus statistical forecasting models. Journal of Futures Markets, 21, 10431069.

Castelino, M. G. (1992). Hedge Effectiveness Basis Risk and Minimum Variance Hedging. The Journal of Futures Markets, 20, 1, 89-103 (2000), Originally published in 1992.

Cecchetti, S. G., Cumby, R. E., \& Figlewski, S. (1988). Estimation of optimal futures hedge. Review of Economics and Statistics, 70, 623-630.

Choudhry, T. (2004). The hedging effectiveness of constant and time-varying hedge ratios using three Pacific Basin stock futures. International Review of Economics and Finance, 13, 371-385.

Ederington, L. H. (1979). The Hedging Performance of the New Futures Markets. The Journal of Finance, 36, 157-170.

Fama, E. F., (1965). The behavior of stock prices. Journal of Business, 38, 34-105.

Fama, E. F., \& French K. R. (1987). Commodity future prices: some evidence on forecast power, premiums, and the theory of storage. Journal of Business, 60, 55-73.

Floros, C., \& Vougas, D. V. (2006). Hedging effectiveness in Greek Stock index futures market 1999-2001. International Research Journal of Finance and Economics, 5, 7-18.

Frank J., \& Garcia P. (2008). Time-varying risk premium: further evidence in agricultural futures markets. Applied Economics, 1-11.

Ghosh, A., (1993). Cointegration and error correction models: intertemporal causality between index and futures prices. Journal of Futures Markets 13, 193-198. 
Holmes, P. (1995). Ex ante hedge ratios and the hedging effectiveness of the FTSE-100 stock index futures contract. Applied Economics Letters, 2, 56-59.

Johnson, L. (1960). The theory of hedging and speculation in commodity futures. Review of Economic Studies, 27, 139-151.

Kavussanos, M. G., \& Nomikos, N. K. (2000). Constant vs. time varying hedge ratios and hedging efficiency in the BIFFEX market. Transportation Research Part E, $36,229-248$.

Lien, D. (1996). The effect of the cointegrating relationship on futures hedging: a note. Journal of Futures Markets, 16, 773-780.

Lien, D., \& Luo, X. (1994). Multi-period hedging in the presence of conditional heteroscedasticity. Journal of Futures Markets, 14, 927-955.

Lien, D., Tse, Y. K., \& Tsui, A. C. (2002). Evaluating the hedging performance of the constant-correlation GARCH model. Applied Financial Econometrics, 12, 791798.

Lypny, G., \& Powalla, M. (1998). The hedging effectiveness of DAX futures. European Journal of Finance, 4, 345-355.

Mazaheri, A. (1999). Convenience yield, mean reverting prices, and long memory in the petroleum market. Applied Financial Economics, 9, 31-50.

Mandelbrot, B. (1963). The variation of certain speculative prices, Journal of Business. 36, 394-419.

Moosa, I. A. (2003). The sensitivity of the optimal hedging ratio to model specification. Finance Letter, 1, 15-20.

Myers, R. J., (1991). Estimating time-varying optimal hedge ratios on futures markets. Journal of Futures Markets 11, 139-153. 
Myers, R.J., \& Thompson, S. R. (1989). Generalized optimal hedge ratio estimation. American Journal of Agricultural Economics, 71, 858-868.

Park, T. H., \& Switzer, L. N. (1995a). Bivariante GARCH estimation of the optimal hedge ratios for stock index futures: a note. Journal of Futures Markets 15, 61-67.

Park, T. H., \& Switzer, L. N. (1995b). Time-varying distributions and the optimal hedge ratios for stock index futures. Applied Financial Economics, 5, 131-137.

Pennings, J. M. E., \& Meulenberg, M. T. G. (1997). Hedging efficiency: a futures exchange management approach. Journal of Futures Markets, 17, 599-615.

Rolfo, J., (1980). Optimal Hedging under Price and Quantity Uncertainty: The Case of a Cocoa Producer. Journal of political ecomomy, 88, 100-116.

Roy, A., \& Kumar, B. (2007, June). CASTOR SEED FUTURES TRADING: Seasonality in Return of Spot and Futures Market. Paper presented at the $4^{\text {th }}$ International Conference of Asia-pacific Association of Derivatives (APAD), Gurgaon, India.

Silber, W. (1985). The economic role of financial futures",. In A. E. Peck (Ed.), Futures markets: Their economic role. Washington, DC: American Enterprise Institute for Public Policy Research.

Tong, W. H. S. (1996). An examination of dynamic hedging. Journal of International Money and Finance, 15, 19-35.

Yang, W. (2001). M-GARCH hedge ratios and hedging effectiveness in Austrailan futures markets. Paper, School of Finance and Business Economics, Edith Cowan University. 


\section{APPENDIX}
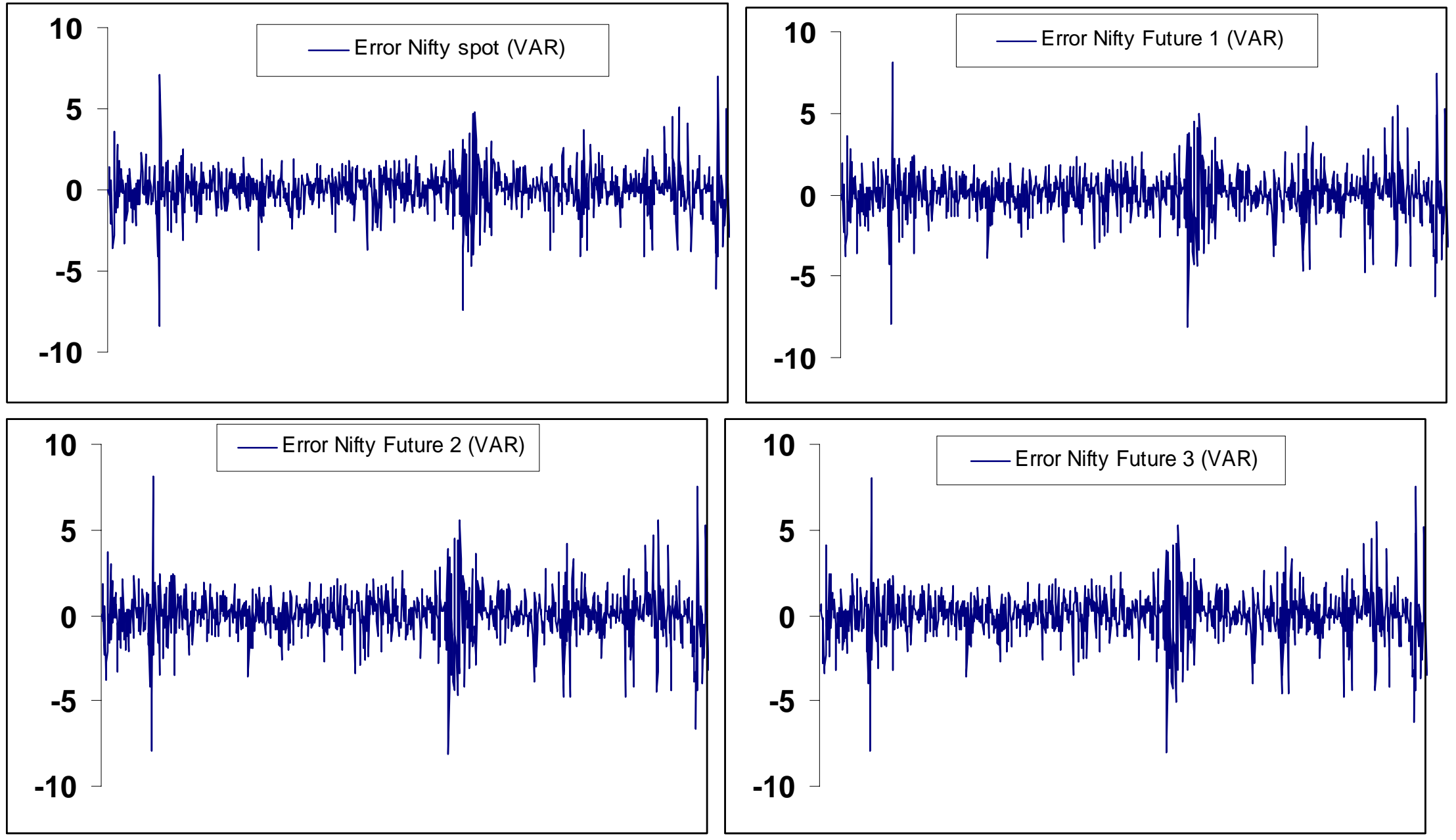

Figure 1: Residual series from spot and futures equation in VAR model for nifty 

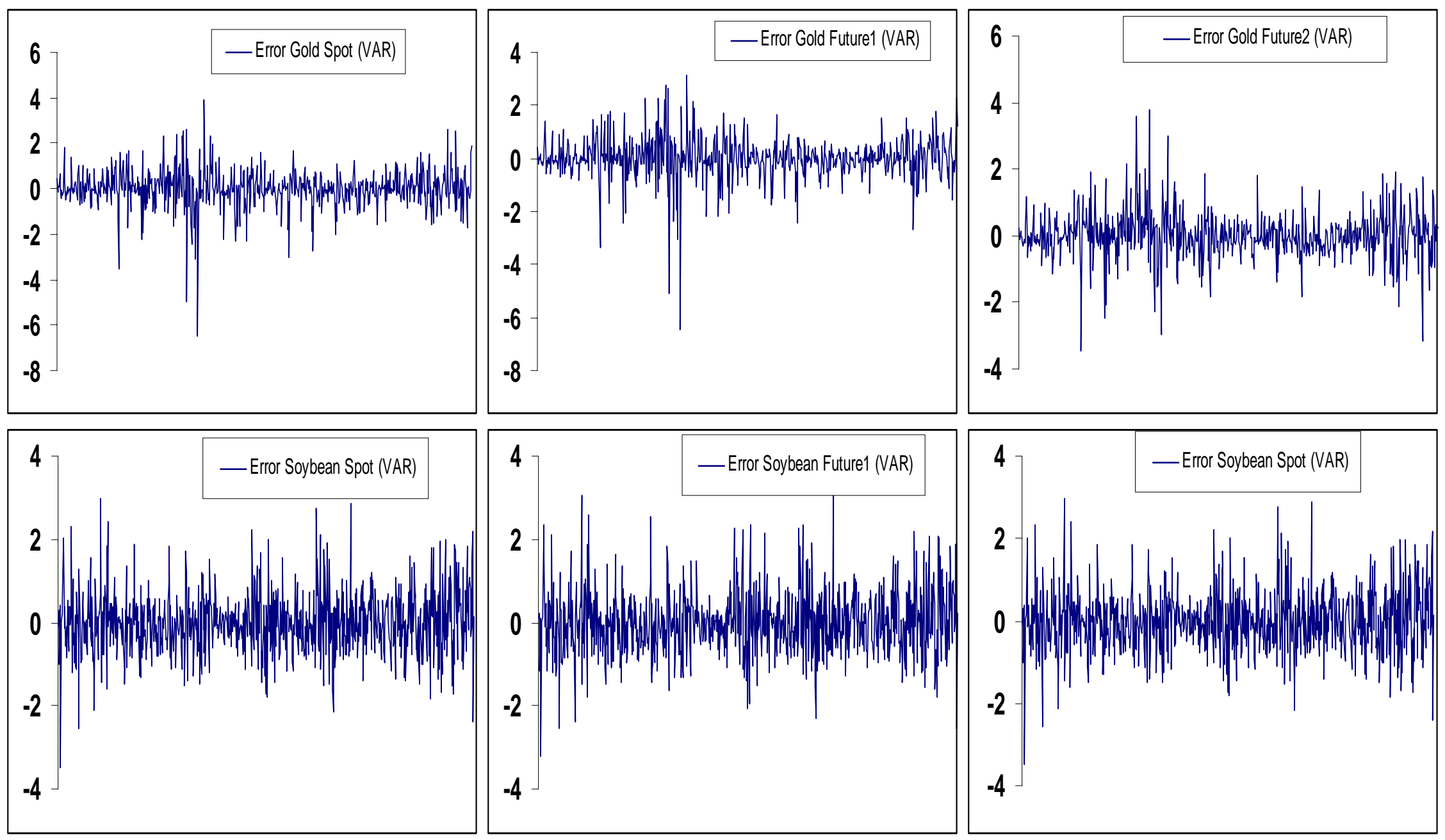

Figure 2: Residual series from spot and futures equation in VAR model for Gold and Soybean 

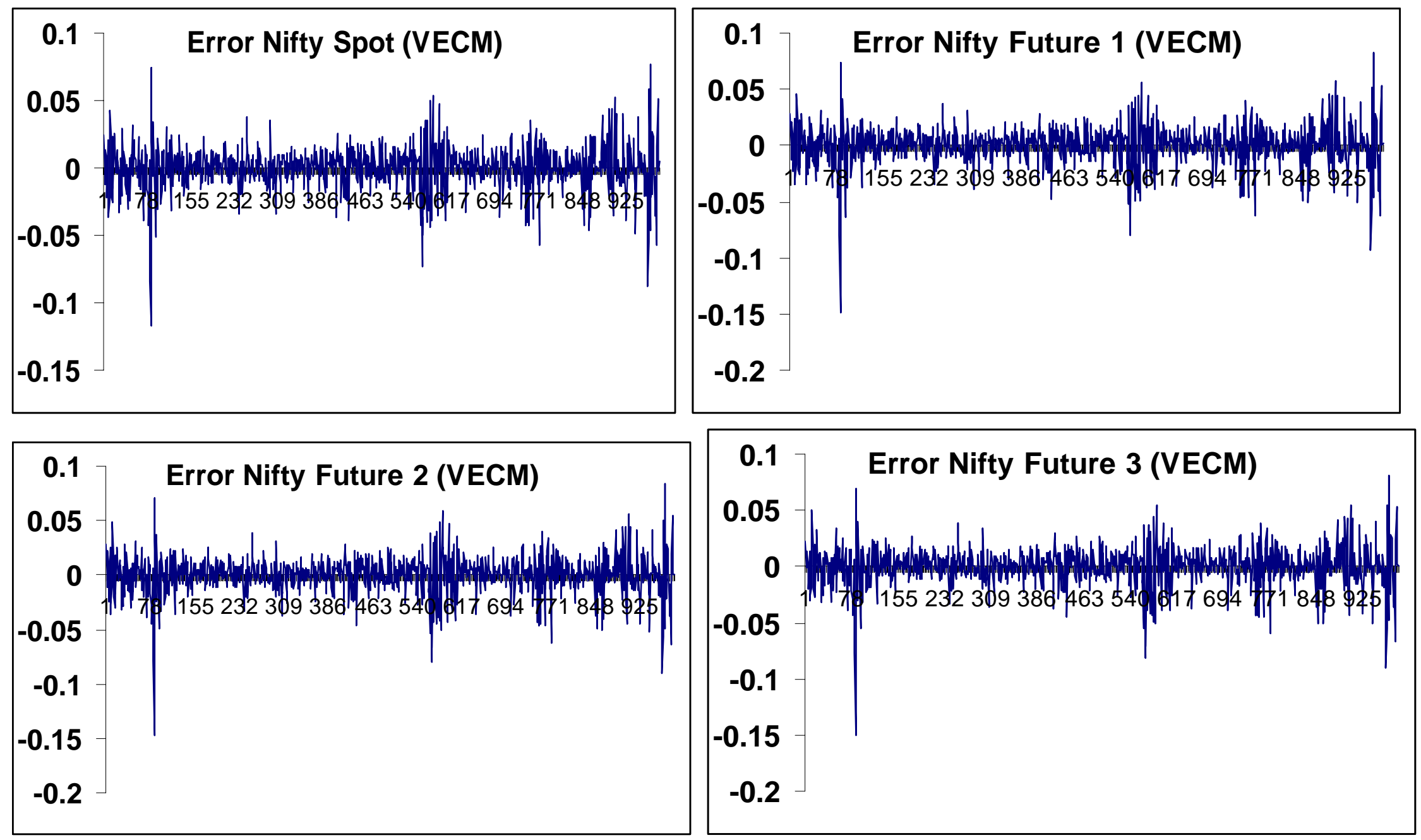

Figure 3: Residual series from spot and futures equation in VECM for Nifty 

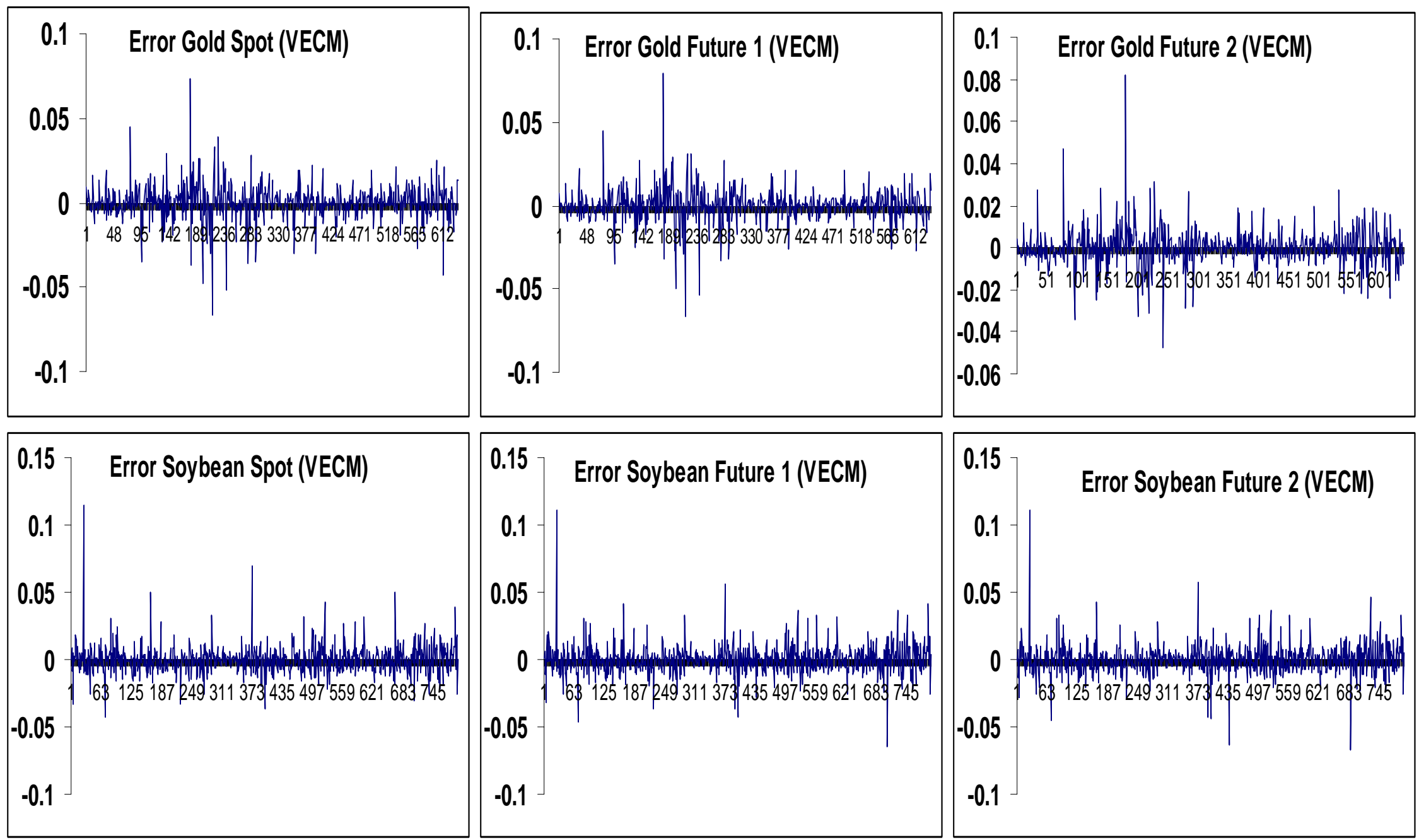

Figure 4: Residual series from spot and futures equation in VECM for Gold and Soybean 